\title{
التنبؤ بالتحصيل الأكاديمي من خلال بعض الدوافع والحاجات لدى فئات متنوعة من الموهوبين
}

\section{رانيا البكري الحسيني شهيب}

$$
\begin{aligned}
& \text { استنهفت الدراسة الحالية التتبؤ بالتحصيل الأكاديمي من خلال بعض الدوافع و الحاجات للى فئات }
\end{aligned}
$$

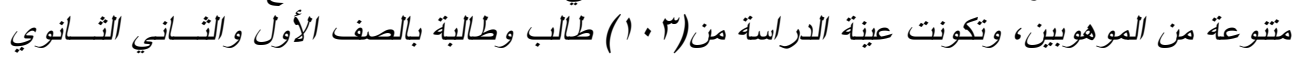

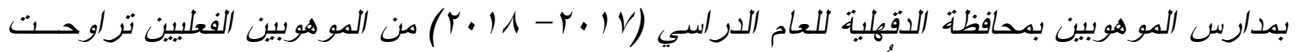

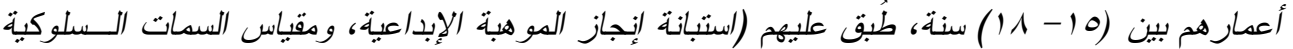

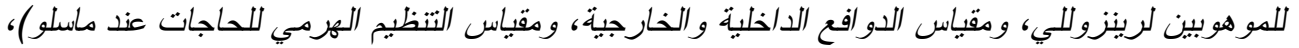

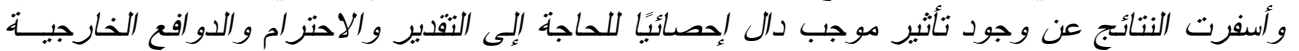

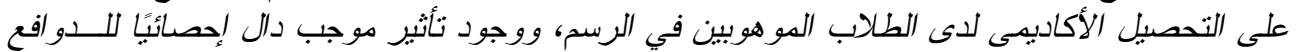

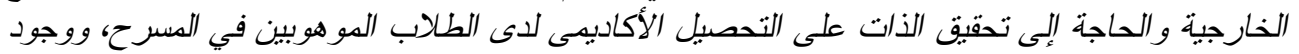

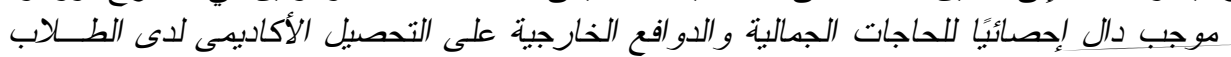

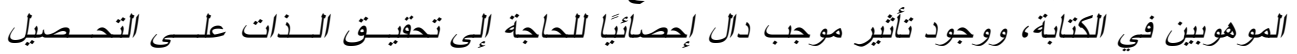

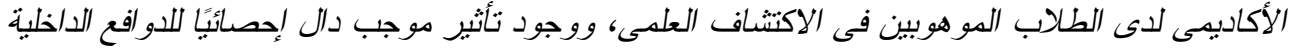

$$
\begin{aligned}
& \text { على التحصيل الأكاديمى لدى الطلاب الهو هوبين في الألعاب الرياضية و الغناء. }
\end{aligned}
$$

Abstract:

The current study aimed at knowing the prediction of academic achievement through some of the motivations and needs of a diverse group of gifted students. The study sample consisted of (103) students in the first and second secondary grades in the gifted schools in Dakahlia governorate for the academic year ( 20172018). Their ages ranged between (15-18 years)، they were applied (Determination of creative talent achievement-a measure of the behavioral characteristics of talented to Renzulli، Scale of internal and external motives، and Maslow's hierarchy of needs). The results yielded a statistically significant effect on the need for appreciation، respect and motivation For the academic achievement of the gifted students in the drawing، a statistically significant influence on external motives، the need for self-achievement on the academic achievement of the gifted students in the theater، and the statistically significant impact of aesthetic needs and external motivations on the academic achievement of gifted students in writing، This is statistically significant for the need to achieve self-achievement on the academic achievement of gifted students in scientific discovery, and a statistically significant effect of internal motivation on the academic achievement of gifted students in sports and singing. 


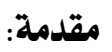

المتفوقين الذين و هبوا الذكاء الممتاز ، كما أنهم

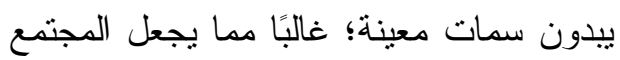
يعقد عليهم الأمل في الإسهام بنصيب و افر في لئي

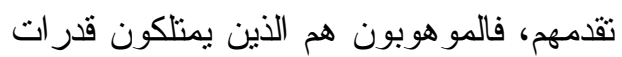

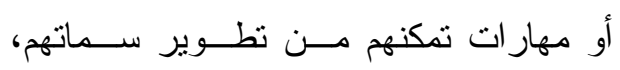
و استخدامها في أي مجال من مجالات النشاط

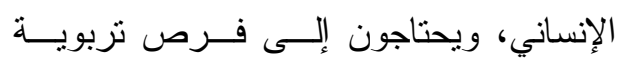

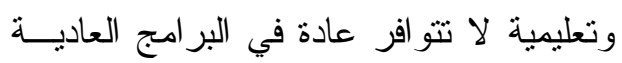

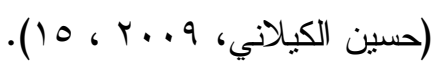
كما أن تعريف الموهبة يدخل ضــــن

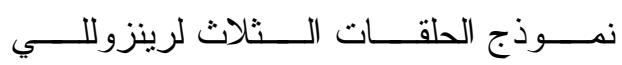
، (Renzulli)

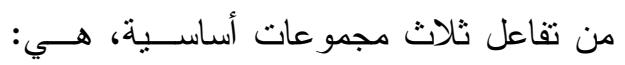

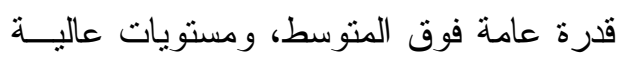

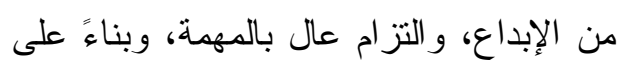

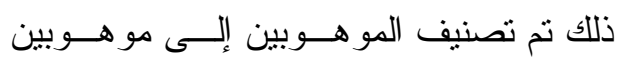
(أكاديميًا - إبداعيًا- فنيًا - قياديًا) .

لقد قدم رينزوللي إضافات كثيرة، من بينها: توسيع مفهوم المو هبة والتفوق، و إبراز

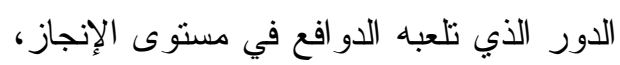

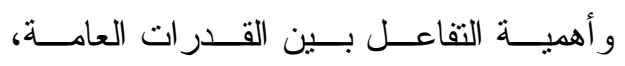
و الإبداعية، و الدو افع بالنسبة لتخطيط البرامج لهين الخاصة للموهــوبين و المتفــوقين (ممــدوح

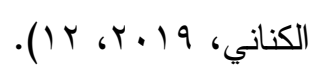
وفي المرحلة الثانوية عنــدما يــصبح

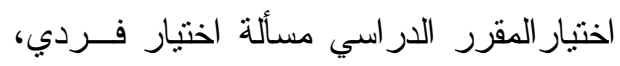

نتيجة التحديات الجوهرية في شـتى مجالات الحياة بمكوناتها العلمية و الثقافيــة و الاجتماعية، ومع تغيير الثقافة المجتمعية،

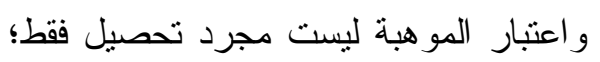

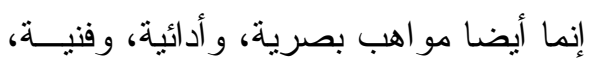

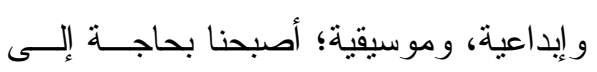

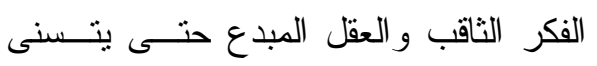

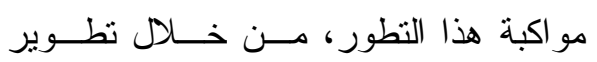

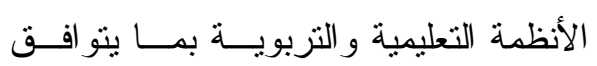

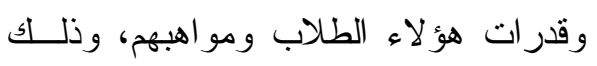

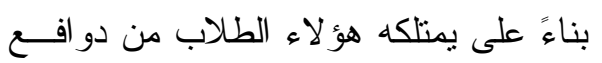
وحاجات نفسية.

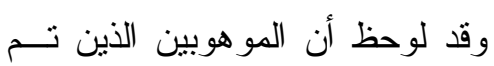
تحديدهم في مجالات، كالإبداع، و القيــادة، و الفنون، وغير ها من المجــالات- لــديهم

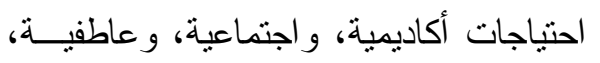
وشخصية، ومهنية فريدة في نوعها كي يتم

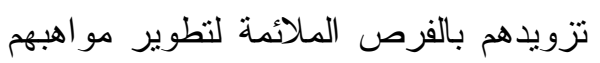

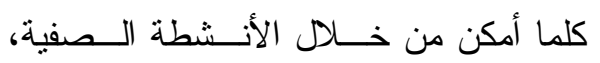
و المدرسية، و عندما لاتلبى تلك الاحتياجات

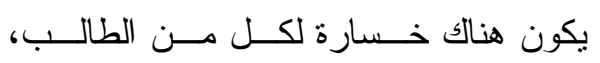

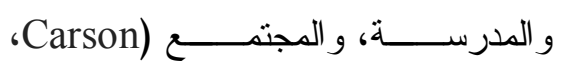
.) 42، 2005،Peterson \& Higgins و المو هوب لغةً يعني الإنسان الــذي

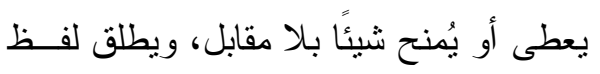

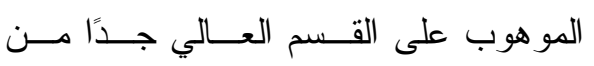


تتظيمه الهرمي للحاجات بدءًا من الحاجــات

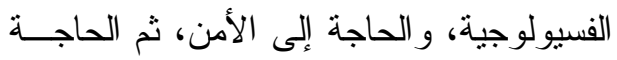

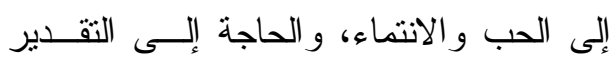

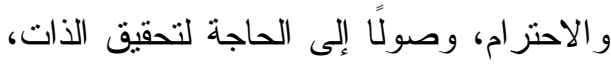
و الحاجة إلى المعرفة و الفهم، و أخيرًا الحاجات

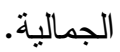

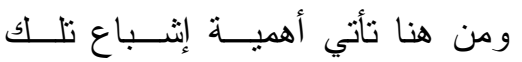

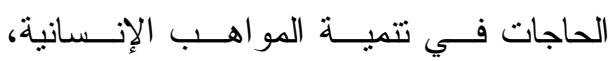
و استثمار ها، وفي المقابل يؤدي حرمان هــــا الإشباع إلى الشعور بالضيق، و الألم، ويتحول هردي

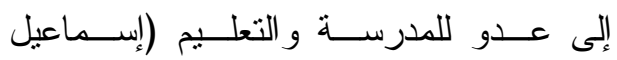

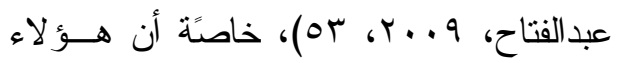
المو هوبين أكثز عرضة للمشكلات الثخصية و الاجتماعية بسبب تميـز هم عـن أقـــر انهم

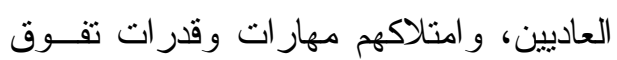
غير هم، لايقدر ها من حولهم من (الأقــــان-

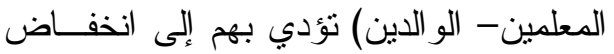
تحصيلهم الأكاديمي، الذي يقصد به أن يكون لؤدي بهن إلى

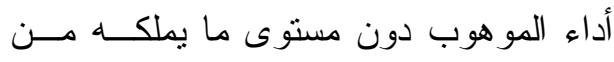

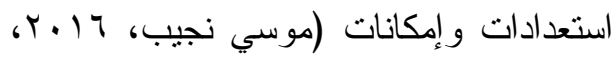
.$(110$

و الدليل على ذلك وجود تلاميذ فـشنلو ا

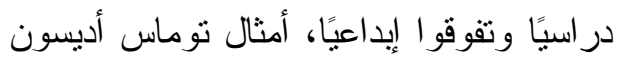
مخترع المصباح الكهربائي، وجورج منــلدل عالم الجينات المشهور ، و العالم نبوتن مكتشف وجن قو انين الجاذبية، وكذلك عالم النظرية النـسبية
تبدأ الفروق الدافعية في إحداث تأثنير حقيقي

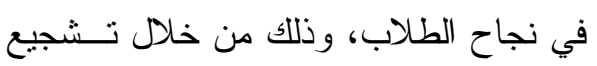
الطلاب ذوي الدافعية بتجنيبهم المنطلبـات ونات

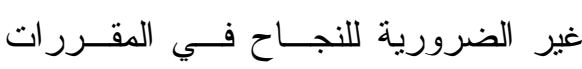
المتقدمة، وتوفير مزيد من العون الأكاديمي

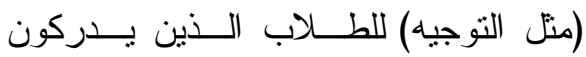

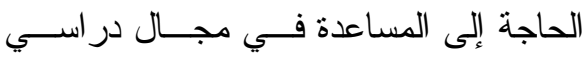

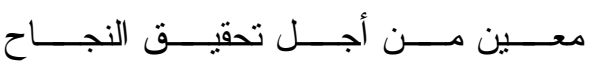

، Jolly، Ritchotte،(Matthews) .382 .2014 وترتكز الدو افع بصورة جزئية على

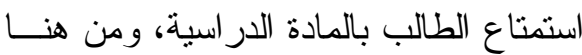
يمكن للتدريس الفعال أن ينشد في إحــداث ، Schommer،Neber(التغيير المرغوب 63،2002 ) )، كما أن الــسجل الأكــاديمي

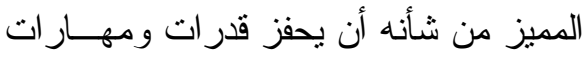
الطالب الموهوب، ويجعله قادرًا على تحقيق ذاته في مو هبته وقدر اته الأكاديمية، و السجل الأكاديمي الضعيف من شأنه أن يقلل مــن الفرص المتاحة أمام هذا الطالــب (Kay) (21،2008 كما أن اتـصاف الموهــوب بقــوة الدافعية نحو التعلم و الاستكثاف تجعل لديه رغبة فــي اكتــساب المهــارات العقليــة و المعرفية التي تشبع لديه الحاجة إلى تقدير الذات، وتحقيقها، وهي من الحاجات التــي

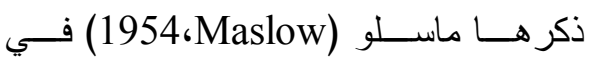


وذللك في حالة الــتعلم القـائم علــى تحقيـــق

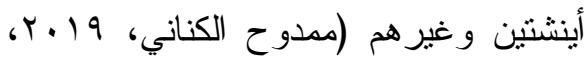

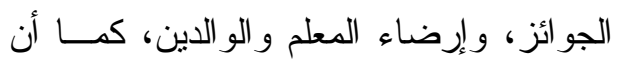

. (r.

هؤلاء الطلاب في المرحلة الثانوية بحاجة إلى ولى

ومما سبق يتـضـح أن للموهــوبين

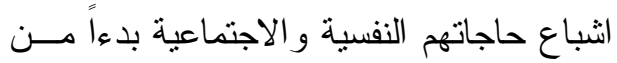

حاجات يجب أن تُشبع كأقر انهم العـاديين،

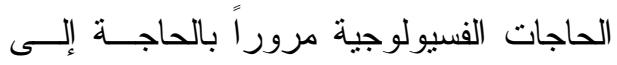

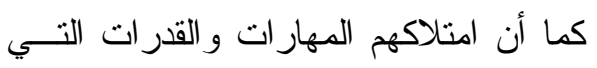

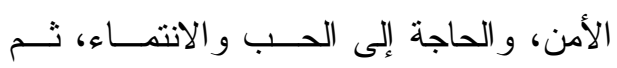

تميزهم عنهم لا يجب أن يكون عائقًا أمسـام

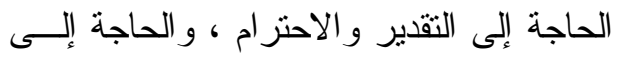

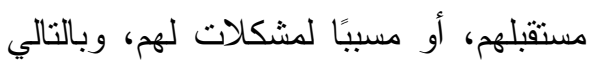

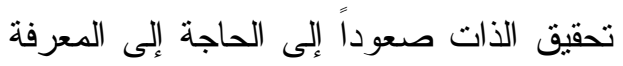

يجب تصحيح الاعتقاد الخطأ بأن الطــلاب

و الفهر و أخير اً الحاجات الجمالية.

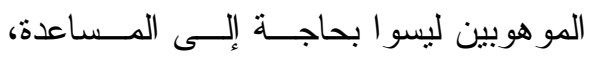

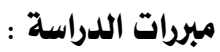

1. اهتمام الدر اسات ببعض أبعاد الدافعيــة

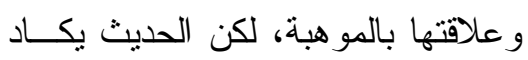

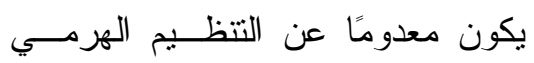

للحاجات عند المو هوبين بشكل عام.

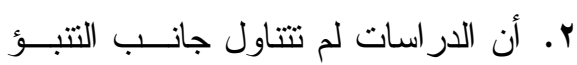

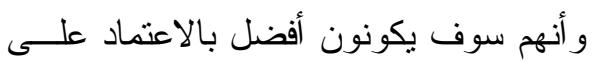
أنفسهم، وأنهم قادرون على إثباع حاجاتهم

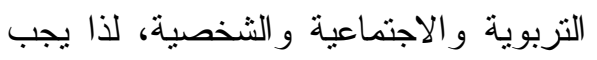

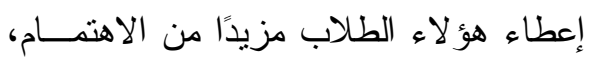

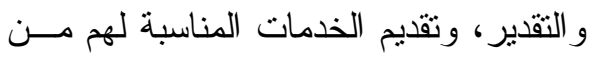
خلال تتمية جو انب القوة لديهم وزيادتهــا، بالتحصيل الأكاديمي من خلا نوع كل بل هل بل

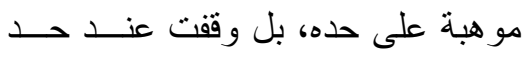
التتبؤ بالمو هبة من خلال الدافعية بشكل عام. ويمكن تحديد مشكلة الدراسة فى التساؤلات و الاستفادة من مو اهبهم وتوجيــــهـ قــدر اتهم التوجيه الملائم الذي يتتاسب مع مايمتلكونه من إمكانات وقدرات، بالإضافة إلى تعرف الطلاب الموهوبين منذفــي التحــصيل،

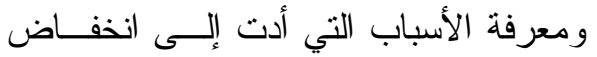
الآتية: - م 1. هل يمكن التتبؤ بالتحصيل الأكــاديمى الهى للطلاب المو هوبين من خلص التتظــيم تحصيلهم ومعالجتها بالطرق المناسبة.

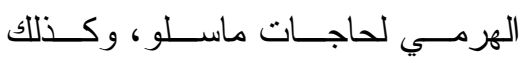

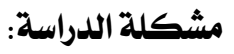
تؤدي الدوافع دورًا مهمًا في تعلــم الطلاب وتحصيلهم، ويكون مصدر الدوافع دو افعهم الداخلية و الخارجية؟

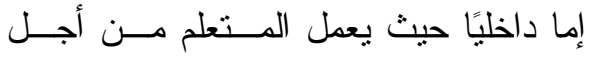
التعلم، وما يوفره التعلم من متعة في عملية التعلم، وتحقيق الإنجاز، وقد يكون خارجيًا، 
موهبة بناءً على العلاقة بين الموهبــة

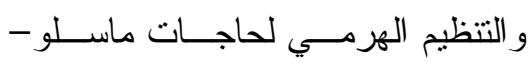
الدو افع الداخلية و الخارجية.

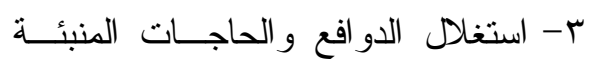

بالتحصيل الأكاديمي و التزكيز عليهـــا

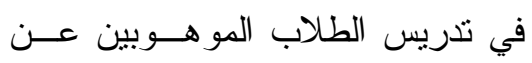

طريق تحسينها وتتميتها.

\section{المفاهيم الإجرائية للدراسة:}

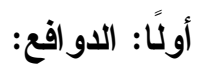

هي قوى تحرك الفرد وتوجهه نحسـو

هدف يرغب في تحقيقه، كما تتحكم فى كثافة الجهد الذى يبذله في أثناء وصوله إلى الهدف،

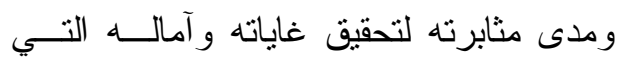
يرجو ها، وتقاس إجر ائياً بالدرجة التي يحصل

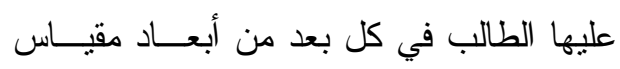
الدو افع (الداخلية و الخارجية).

الدوافع الداخلية: قيام الطالب بالمهــام

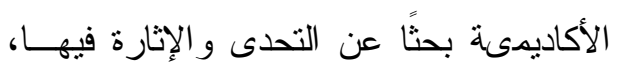
وتجعله مثابرًا ونشطاً فى أدائه، كما تتمى لديه الإنا بعض المهارات التى تميزه عن غيره، كالتقة و الاستقلالية، و التمكن.

الدو افع الخارجية: قيام الطالب بــأداء

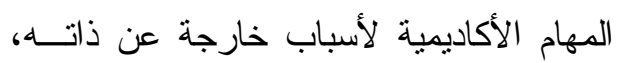

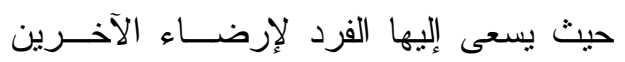

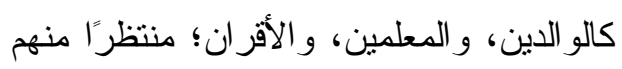

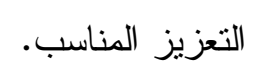

الهرمي لحاجــات ماســلو، وكــذلك

دو افعهم الداخلية و الخارجية باختلاف وله وله

لنوع الموهبة؟

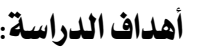

تهدف الدراسة الحالية إلى:

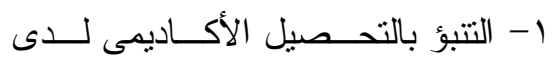

الطلاب المو هوبين من خلال التتظيم

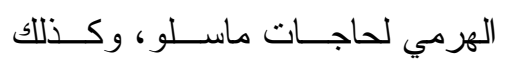

دو افعهم الداخلية و الخارجية.

ץ- معرفة نوع الدافع و الحاجـــة المنبئـــة

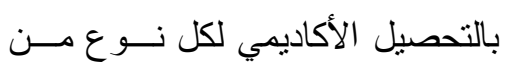

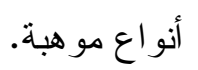

r- معرفة المنبئات القوية والضعيفة من

خلال بعض الدو افع و الحاجات حسب ولب

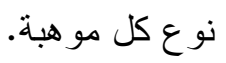

أهمية الدراسة:

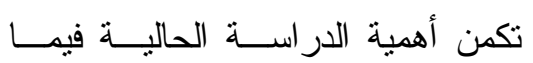
يأتي:

1- إن المو اهب في مجالات (الموسيقى-

الغناء- التمثيل- المسرح- الألعـاب الفي

الرياضية- الكتابة الإبداعية) تعتبـــر

عناصر مشاركة في العملية التعليمية،

فمن خلالهم يمكن إكــــاب الطـــلاب

المهار ات و القـيم و الاتجاهــات دون لهن

تزكها للصدفة.

r- استثمار نتائج الدر اسة في بناء برامج

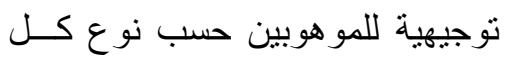


إليه الفرد من تقبل للأخرين، وتمسك بصديق

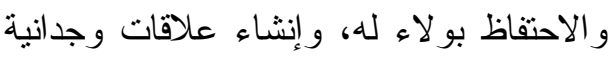

هي الحالة المثالية للفرد- الوضــع

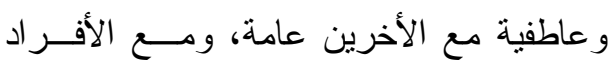

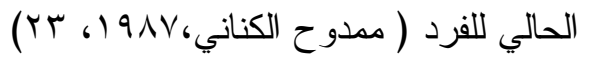

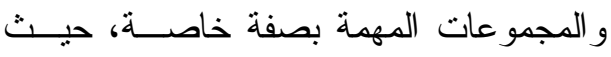

وقد تبنت الباحثة تعريفات ممـدوح

يرتبط و إيــاهم بأهــــاف ومــصالح و آمــال

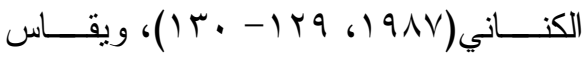

ومخاوف ومعتقدات وقيم و اتجاهات مشتركة،

وقبول لما اتفقت عليه الجماعة مسـن معسايير

إجر ائيًا بدرجة الطالب على كل حاجة مــن

و أنماط سلوكية.

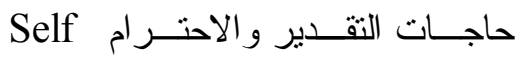

هsteem Needs

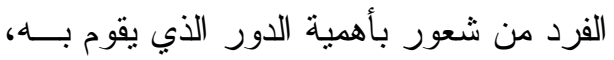

وشعور بالنجاح فيما يقوم به من عمل، وقيام

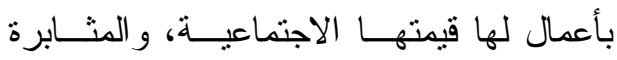
و الإنجاز للوصول إلى ذلك كله.

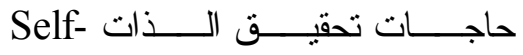
تللك الحاجات، كما يأتي:

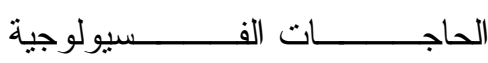

Physiological Needs

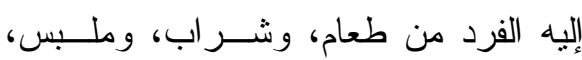
و أكسجين، ونوم، وجنس، واخر اج، وحماية

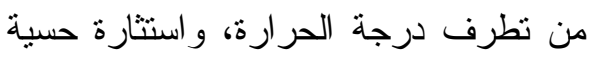
ونشاط، وكفاءة الأعضاء و الأجهزة المختلفة ولنة

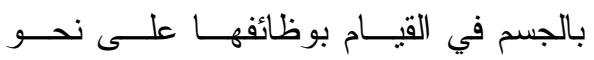
Actualization Needs

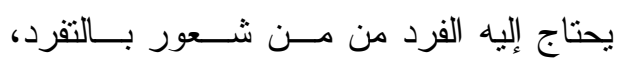

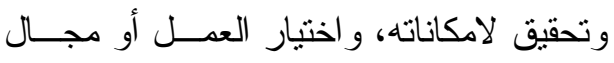

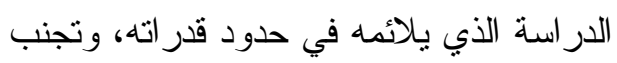

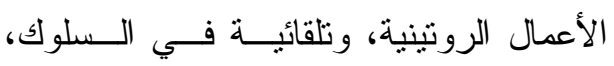

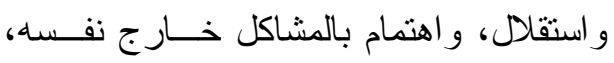
وشعور برسالته في الحياة، واهتمامه بالفكاهة

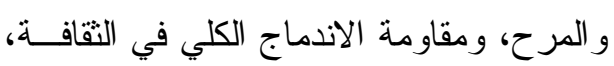

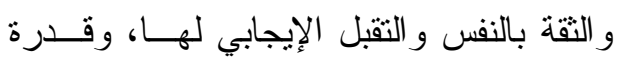
على التقكير الابتكاري.

Needs to اجات المعرفة و الفهـم know and understand مناسب.

حاجات الأمنSafety Needs: هي مقدار ما يحتاج إليه الفرد من حماية لنفـسه ووقايتها من الظروف التي تــشكل خطـــــا عليه، منل التقلبات المناخيــة و الطبيعيــة،

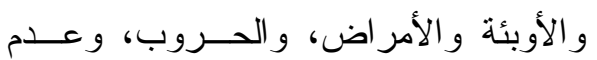
الاستثر ار السياسي و الاقتصادي، والانهيــار

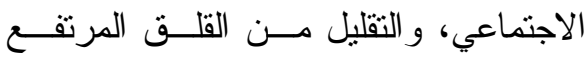
المصاحب للمستقبل المجهول ســـواء فيمــا فيـا يتعلق بدر استه أو عمله أو مأكله أو ملبسه. حاجات الحب و الانتماء Belonging Needs 


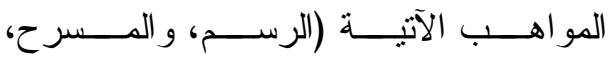

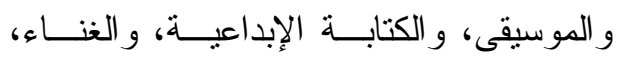

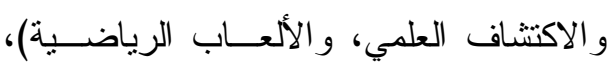

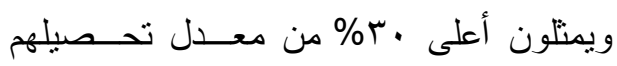

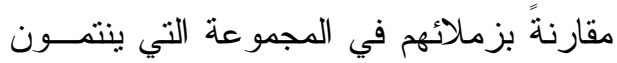

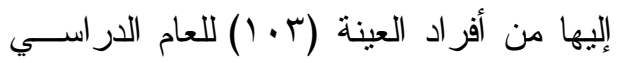

$$
. r \cdot 1 \Lambda-r \cdot 1 V
$$

\section{الموهوبون منخفضو التحصيل:}

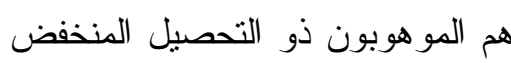

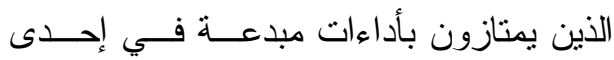

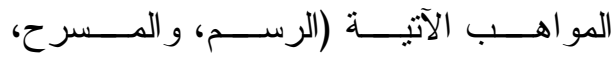

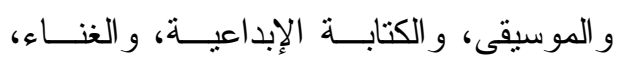

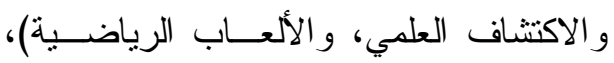

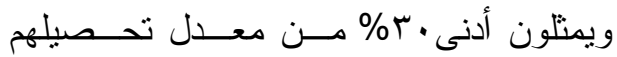
مقارنةً بزملائهم في المجموعة التي ينتمــون

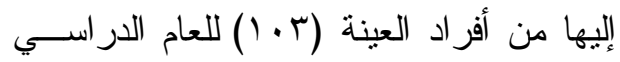

$$
\begin{aligned}
& . r \cdot 1 A-r .1 V \\
& \text { الإطار النظري : }
\end{aligned}
$$

تتــــاول الباحثـــة تعريــف الــدو افع،

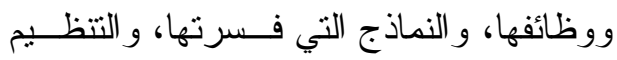

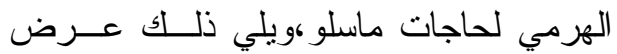

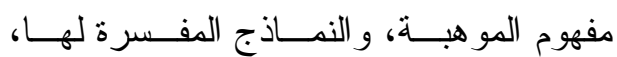

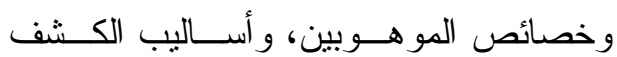

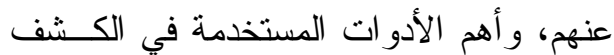
عنهم، وفئات الطلاب المو هوبين.
يحتاج إليه الفرد من اتساق عقلي معرفـي،

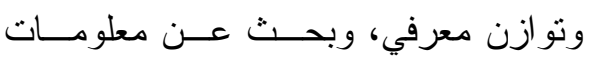

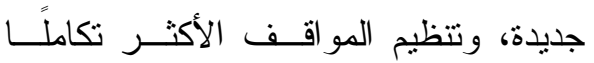

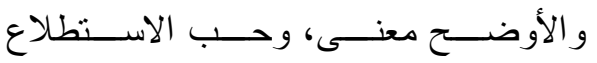

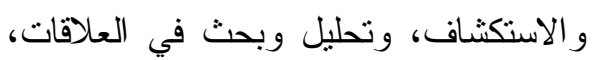

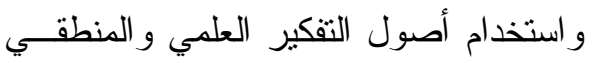
في الإحساس بالمشكلات وصياغتها وحلها.

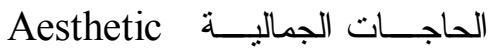
Needs

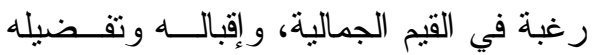
للترتيب و النظام و الاتساق و الكمال سو اء في

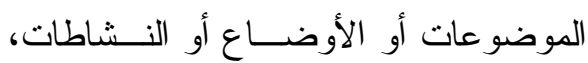

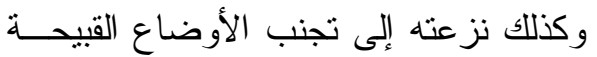
التـــي تــسود فيهــــا الفوضــــى وعــــدم

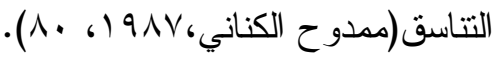
ثانيًا: الموهبة الفعلية (الإتتاجية): هي الموهبة التي يكــون لهـــا أداء

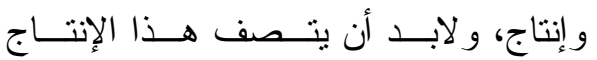
بخصائص، من أهمها الجدة و الاســتمر ارية ولية

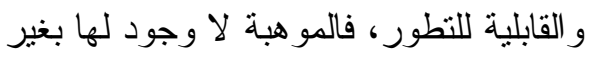
منتج يعبر عنها، بمعنى قيامه بتفعيل مو هبنه

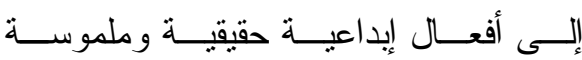

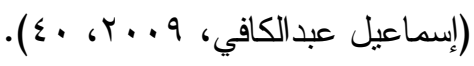
الموهوبون مرتفعو التحصيل: هم الموهوبون ذو التحصيل المرتفع

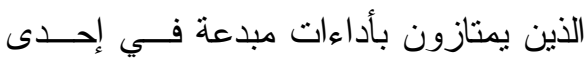




\section{مفهوم الدوافع:}

تعدالدو افع بمثابة قوة ذاتية نابعة مـنـ

الفرد، أو خارجية نابعة من البيئة المحيطة به نيه

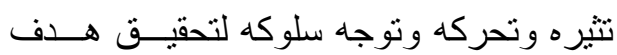
يشعر بأهميته المادية أو النفسية فـى حياتـــه

18)، 2012،(Sealy

وقد تعددت تعريفات الــدو افع بتعـدد

واختلاف وجهات نظر العلماء، حيث يعرفها

كل من عبد الستار إبر اهيم، ورضوى إير اهيم

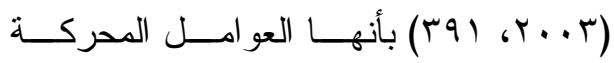

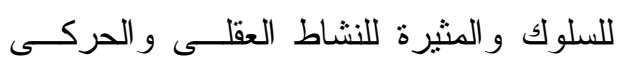
و المسئولة عن استمر ارية النشاط المؤدى إلى ولى لمئى إثباع الحاجة العضوية و النفسية.

كما يعرفها محمود منسـي (Y....T.

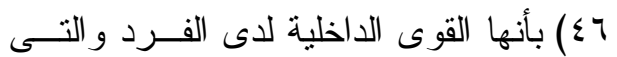

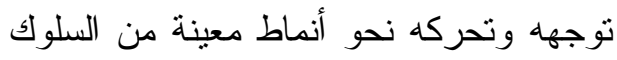

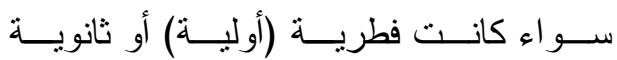
(مكتسبة)، وكل دافع له مثير و انفعال يصاحبه

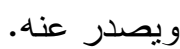

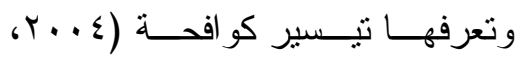

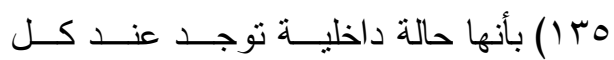
الأفراد، وتؤدى إلى استثارة سلوكهم، وتعمل بانه

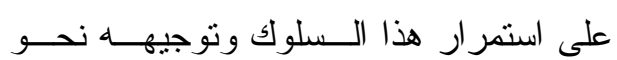
تحقيق هدف معين، وهو مفهوم عام لا يسنتثير

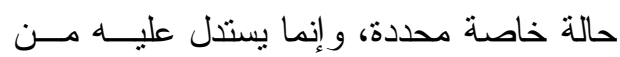
سلوك الأفر اد فى المو اقف المختلفة.
أولًا: الدوافع

تُعد الدوافع العامل الرئيس الذى يقف

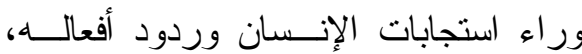
و التى تكون بمثابة المحرك و الموجه نحسـو تحقيق هدفه، وقد نكون تللك القوى داخلية أو خارجية أو مدفو عة بشكل ثنائى (داخلـــــ

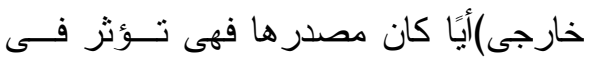
سلوك الفرد و اتجاهاته وقيمــهـ ومعتقداتــه،

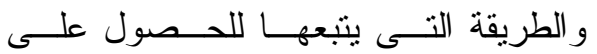

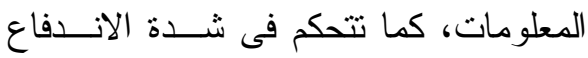

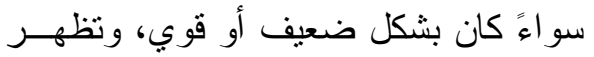

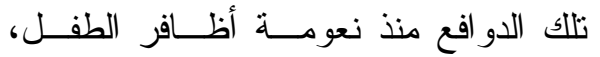
وتستمر معه حتى نهاية العمر.

ولعل هناك الكثير من المـشـاهدات

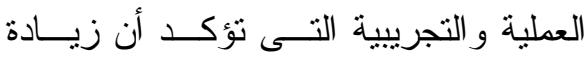
الدو افع إلى حد معين يؤدى إلـى تـسـهيل

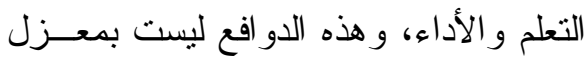

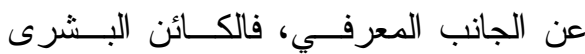
مخلوق عاقل يتمتع بإر ادة حرة تمكنه مــن

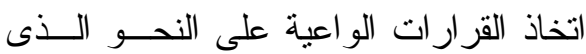

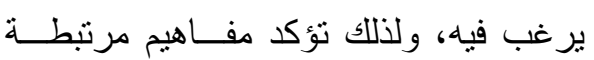

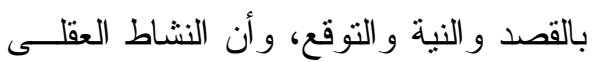

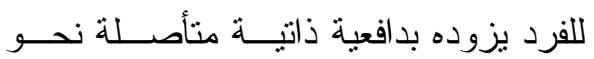

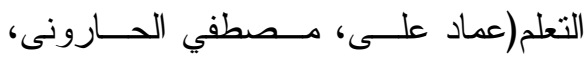
(IV G Y . . E 
ז- إستثاري: فالدافع لا يـسبب الـسلوك،

ودائمًا يستثير الفرد للقيام بالسلوك. لفكائ

أنواع الاوافع:

تفسر الدوافع من خلال نظرية التقرير

الذاتى التى تفترض أن الطلاب يقومون بأداء

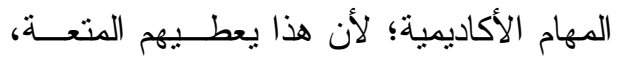

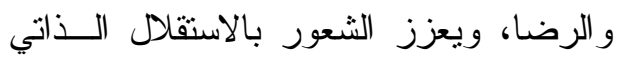

لديهم (11،2013،Clevenger)

كما تتأثر الدو افع للتعلم بعلاقة الطلاب

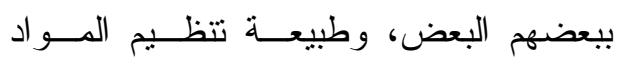

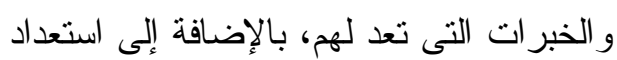

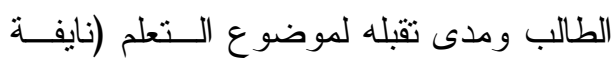

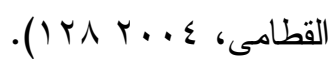

Deci \& ( ) ويرى كل من ديسى وريان

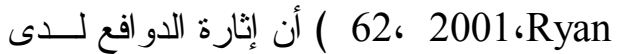

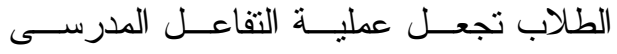
و الصفي أكثر إيجابية وتزيد مـن حماسـهـ للاشتر الك فى مو اقف التعلم الصفي.

كما يشير كمال عطية (......

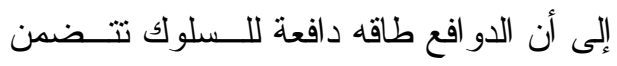

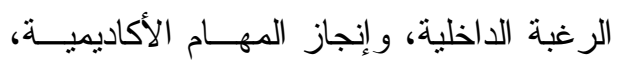

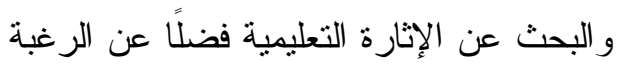

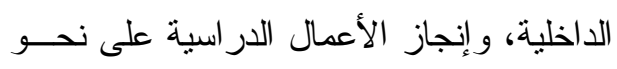

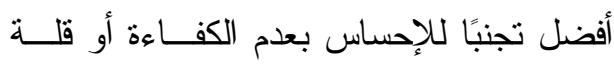
الإمكانيات.

\section{وظائف الدو افع:}

تعددت وظائف الدو افع من كونهــا

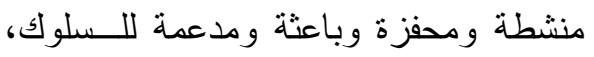

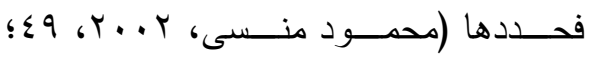

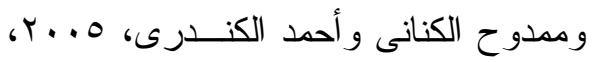

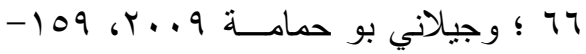

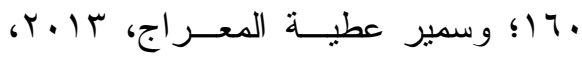

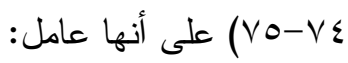

1- منشط: يعمل علـى تـــشيط الفـرد للموقف التعليمى، ويحـرر الــسلوك لكعل وينقله من حالة السكون إلـى حالـــة الحركة، وتمد السلوك بالطاقة وتثير

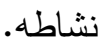
ץ- موجه ومنظم: يوجه سلوك الفــرد إلى وجهات معينة نحو هدف معـين ليحقق له إثباعات معينة.

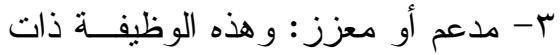
صلة وثيقة بالوظيفة الثاينة وذلك لأن توجيه السلوك لتحقيق أهداف معينـــة

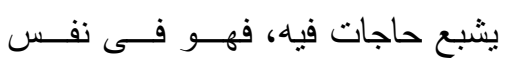

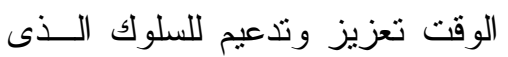
أدى إلى هذه الاشباعات.

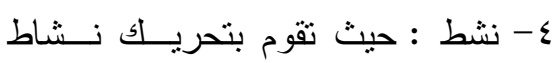

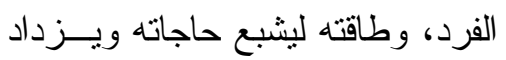
النشاط بزيادة قوه الدافع. 0- استمر اري: فيستمر سلوك الفرد حتى يتحقق الإثباع المطلوب. 


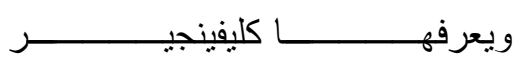

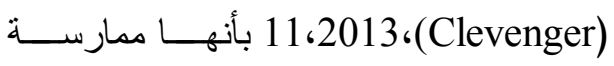
الفرد نثاطاً من بدون الرغبة في المكافأة بـلـل

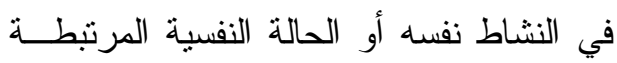

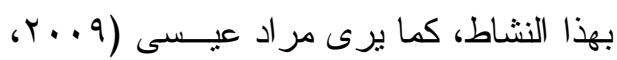

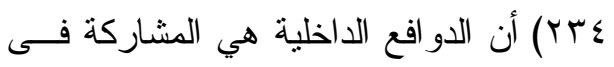

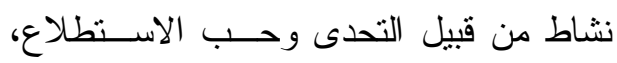
و الإتقان المستقل.

ومن مظاهر الدوافع الداخلية للطلاب

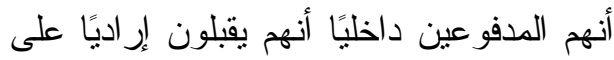

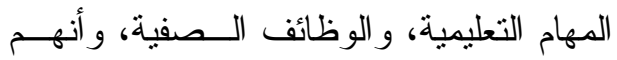

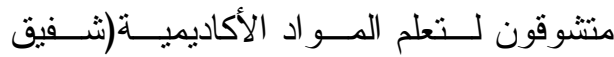

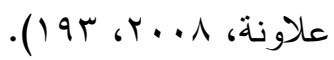

Extrinsic

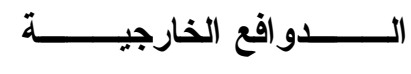

:motivation

يكون مصدرها خارجيًا، حيث يقـوم

المتعلم بسلوك ما؛ بهدف المكافآت الخارجيــة

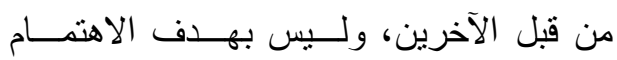

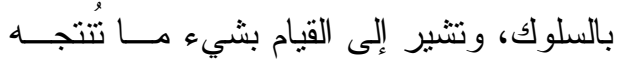

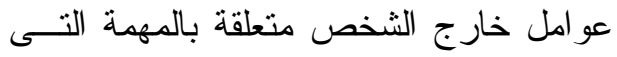

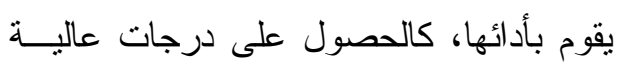
فى الامتحان، أو حصول المتعلم على جـائزة لإنجاز عمل ما، أو سماع كلمات مدح من قبل الأل المعلم أو الو الدين.

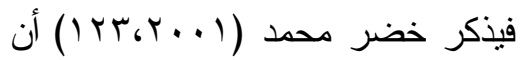

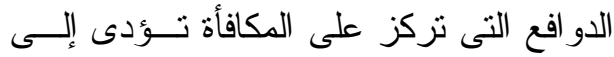

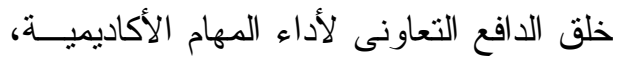

كما اتققت العديد من الأدبيات علـى إنى تصنيف الدوافع إلى دوافع داخلية وخارجية ،Lepper؛ 2001،Deci \& Ryan)

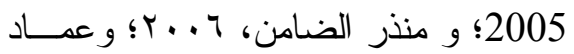

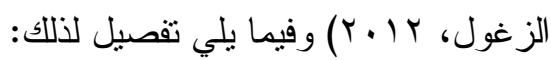

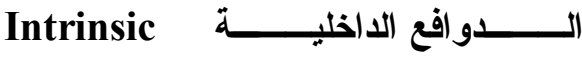
:motivation

يكون مـصدر ها المـتـعلم نفـسه، فيصبح أكثر كفاءة وثثة، واستقلالية، وتشير

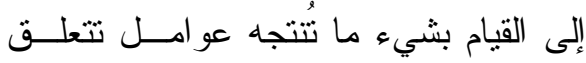
بالثخص نفسه أو بالمهمة التى يقوم بأدائها،

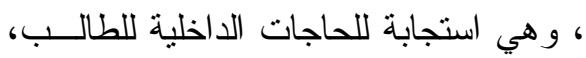

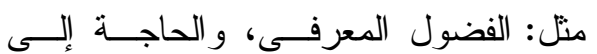
المعرفة، و الثعور بالكفاءة و النمو.

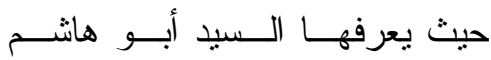

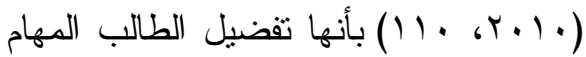
الأكاديمية التي تتطلب التحدي، والمثنـابرة، وحب الاستطلاع، و التمكن المستقل.

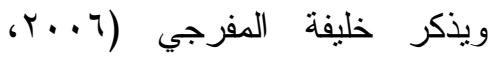
17 (1) بأن مصدرها عو امل داخلية نابعة من المتعلم نفسه، حيث يقدم على التعلم مدفو عًا برغبة داخلية لإرضاء ذاته وسعيًا وراء الثعور بمتعة التعلم معنويًا، وكسب لإنباء المعارف و المهار ات التي يحبها ويميل إليها؛ لما لها من أهمية بالنسبة له. 
ثانياً: الموهوبون

إن نعمة العقل من أعظم الــنعم التـي

فضل الله بها الإنسان عن سائر المخلوقــات،

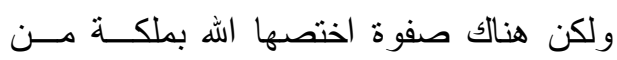
المو هبة و التفوق بشكل غير عادي في مجـــال

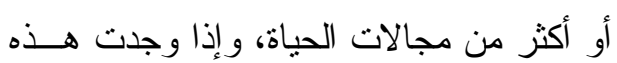
الصفوة الاهتمام و الرعاية ساعد على ظهـــور العديد من المبدعين و المبتكرين و العلماء؛ لذلك

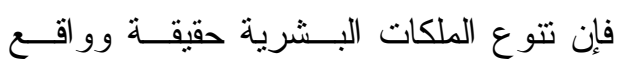

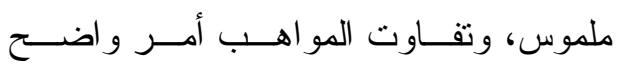
ومشاهد يمن الله بها على من يشاء من عباده،

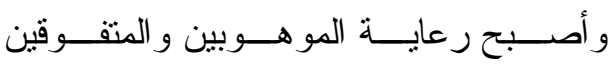

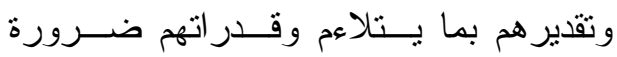
و استر اتيجية مهمة من استر اتيجيات التتـشئة

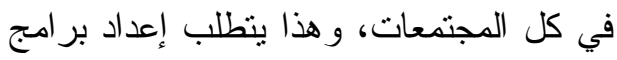
تعليمية خاصة بهم، ووضع مقرر ات و اتبــاع

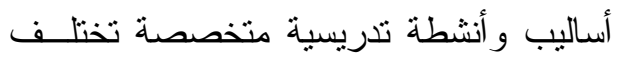

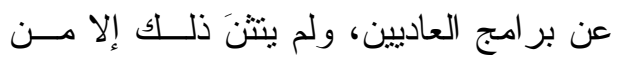

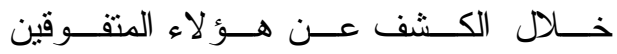
و المو هو بين و المبدعين ور عايتهم.

\section{تعريف الموهوبين:}

اختلف المتخصصون في التربية وعلم

النفس إلى درجة كبيــرة فــي التقرقــــة بــين المو هبة (Talent) (Tifted)؛ وذونلك التفوق لاختلافهم في المحكات التــي تحـدـد وتبــين

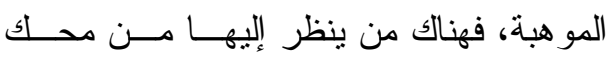

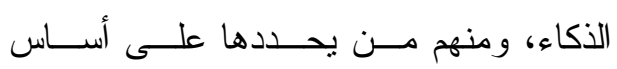

فنجاح المجموعة يحقق للـشخص أهدافــــ الثخصية، كما يحقق أهــــاف المجموعـــة، وبالتالي يحدث تلاحم اجتماعي.

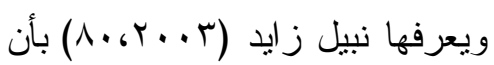
الفرد يكون محكومًا بمصادر خارجية، مثل

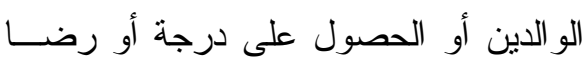

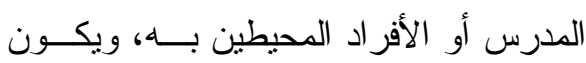

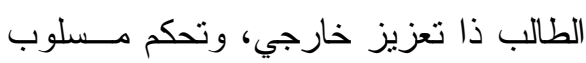

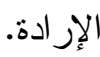
التنظيم الهرمي للحاجات عند ماسلو: يبدأ النمــوذج الهرمــي بالحاجـات الفسيولوجية التي تشمل غالبية الأفراد، بينما باديات تأتي الحاجات الجمالية على قمة ضيقة تشير

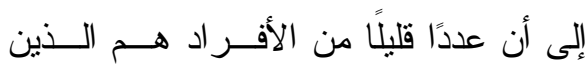
يصلون إليها، وقد يثنير هذا التقسيم الهرمي إلى إعتبار ات تأصيلية بمعنى أن الحاجــات

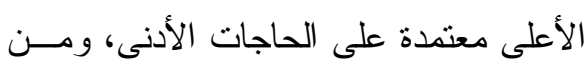
ثم اعتبار الحاجات الفسيولوجية تتبثق منها،

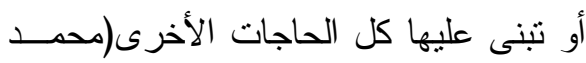

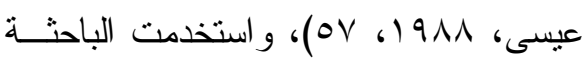

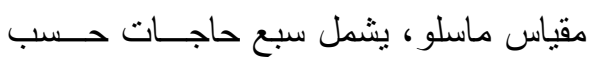

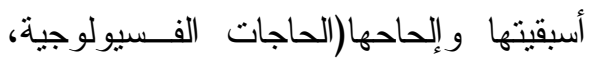
وحاجات الأمن، وحاجات الحب و الانتمــاء،

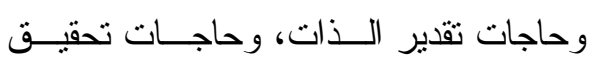
الذات، وحاجات المعرفة و الفهم، و الحاجات (الجمالية). 
(model

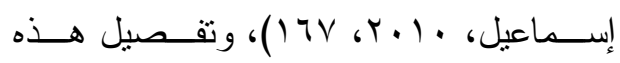
النماذج فيما يلي: 1. نموذج سترينبرج:

يقوم نموذج سترينبرج (Sternberg)

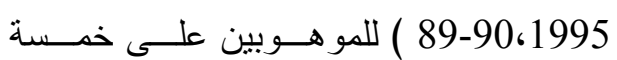
مفاهيم، هي خصائص للمو هوبين : • التمييز (Excellence): أن يكون الفرد فئس منميزًا في بعد ما، أو كل الأبعاد مقارنة بزملائه، وذلك حتى يكون مو هوبًا. • الندرة (Rarity): تميزه في هذا الثيء غير شائع بالنسبة لأقز انه. تئه الإنتاجية (Productivity): يجــب أن يكون الثيء المتميز به مؤديًا إلى الإنتاج (أن يكون منتجًا).

- التحقق (Demonstrability): أن ينم التحقق من كونه موهوبَّـا مــن خــلال

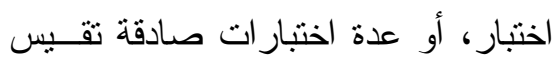
المو هبة (كاختبار القــدرة أو اختبــار ات ات (التحصيل). - القيمة (Value): أن يكون أداؤه المتميز

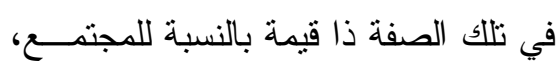
و هذه القيمة نسبية تختلف من ثقافة إلـى أخرى. ويمكن توضيح ذلك النموذج في الثكل الآتي:
التحصيل الدراسي، و هناك من يحددها بناءً

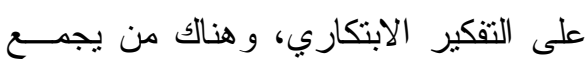

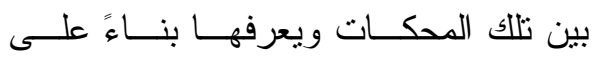
محكاتها المتعددة.

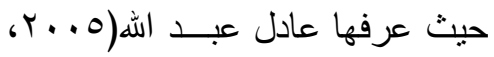
ب بأنها استعداد فطري يولد الفرد مزودًا

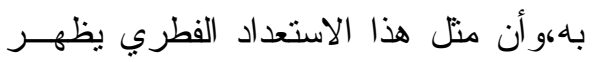
في سلوك الطفل علــى هيئــة مؤشـــرات للمو هبة أو أدلة على وجودها.

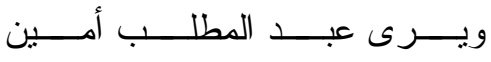

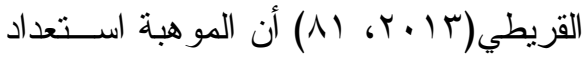
طبيعي أو طاقة فطرية كامنة غير عادية في

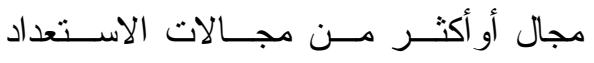
الإنساني التي تحظى بالتقدير الاجنماعي في

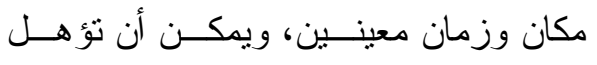

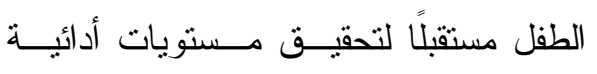
متميزة في أحد ميادين النـشاط الإنـسـاني المرتبطة بهذا الاستعداد، إذا ما تو افرت لديه

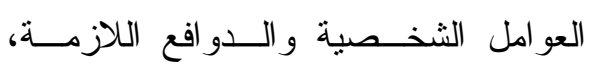
وتهيأت له الظروف البيئية المناسبة. النماذج المفسرة للمو هوبين: لخص سترينبرج وديفيدسون النماذج

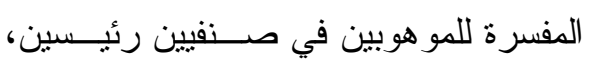

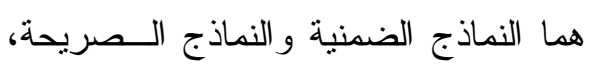

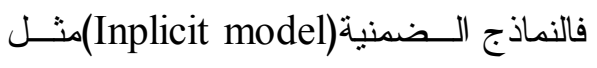
نموذج (رينزوللــي، وجلاجــار ، وجانيــه، و القريطي)، و النماذج الصريحة ( Explicit 


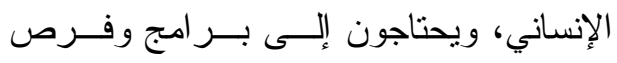

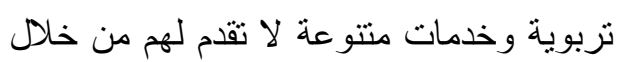
البرامج العادية، ويوضح الثكل الآتي مفهوم

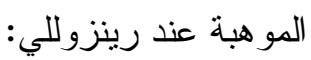

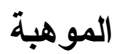

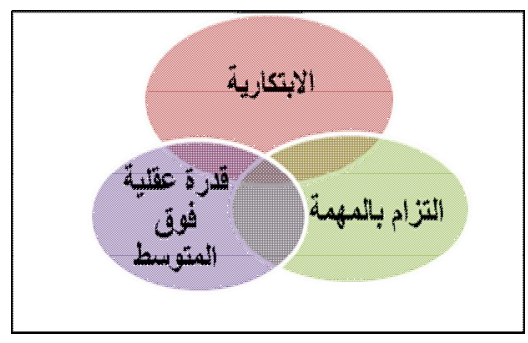

شكل (r) نموذج الحلقات الثثلاث لرينزوللي

(152، 2010،Renzulli)

وقد قامت الباحثـة باتخــاذ نمــوذج

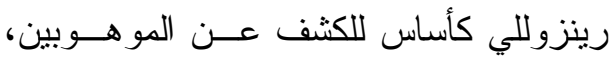
حيث يقوم على افتر اض أن الأفر اد الموهوبين يمنلكون ثلاثاً من السمات المتداخلة و المعروفة بالحلقات الثلاث، وهي (القرة العقلية فــوق

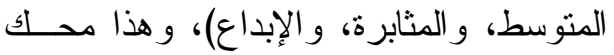
رئيس لتعرف الطلاب الموهوبين. r. نموذج جانييه:

حدد جانييـــ (121،2004،Gagne) في نموذج مكون من 7 مكونات متفاعلة مــع

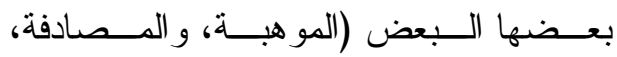

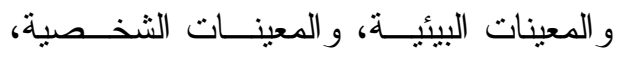
و التعليم و الممارسة، و التفوق)، حيث ميز بين

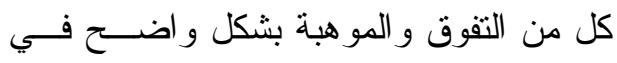
نموذجه المميز، كما يظهر في الثكل الآتـي:

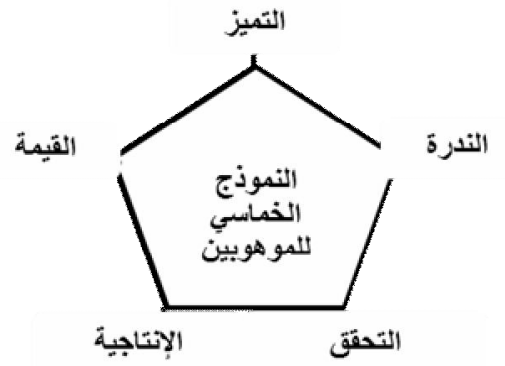

شكل( ) نموذج سترينبرج الخماسي للموهبة ( ) 89-90، 1995،Sternberg

ويلاحظ من نموذج ســنرنبر ج أنــهـ

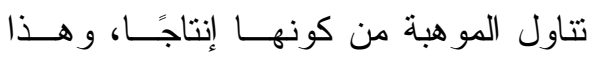
ماتتبناه الباحثة في در استها، حيث استهدفت الدر اسة فئة الموهوبين فعلياً (الــذين لــديهم

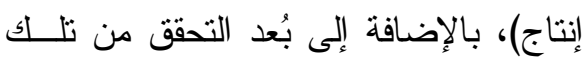

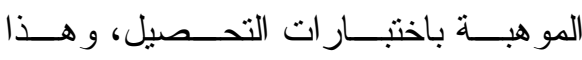
ماستفادت منه الباحثة في أثناء اختبار عينة

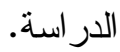

r. نموذج الحلقات الثلاث لرينزوللي:

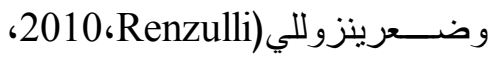
142:143) نموذج الاثر اء الثلاثي لمفهــوم الحلقــات الــثناثلاث مــن تفاعـلـل ثـــلاث مجموعات،هي: قدرة عقلية فوق المتوسط،

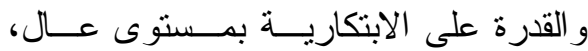

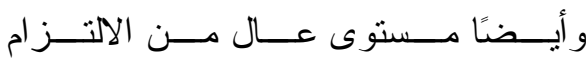
بالمهمة(المثابرة)، وتتفاعل تلك المجموعات

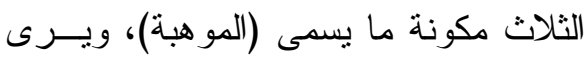

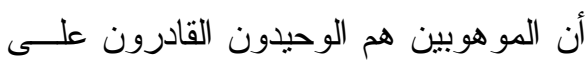
تطوير هذه الجوانــب المهوــة مــن الأداء 
التفوق

الموهبة

عوامل وسيطة ميادين البراعة (عامة ونوعية)

مجالات القدر

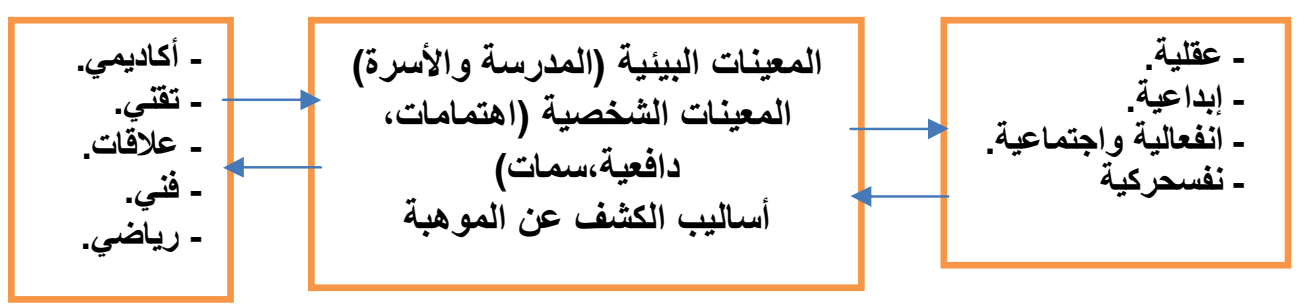

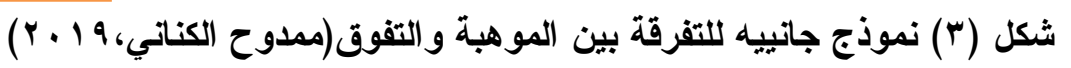

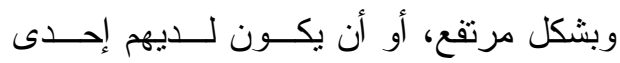
ومما سبق، يُلاحظ مايلي:

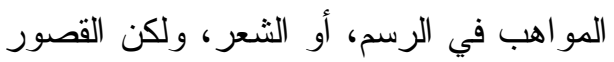

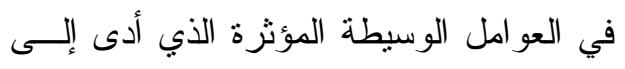
تكون المو اهب عند جانييه في البداية عدم ظهور وبزوغ تللك المو اهب لدى هؤلاء الطلاب (الموهوبين منخفـــي التحــصيل)، و هم جزء من عينة دراسة الباحثة. قدر ات خام أو مكونات أساسـيـة لتـشكيل التفوق لاحقاً في حالة تلقي الفرد ومــروره

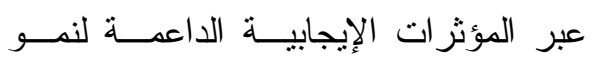
خصائص الموهوبين:

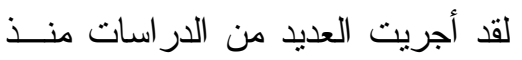

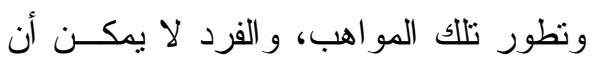

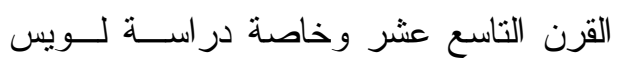

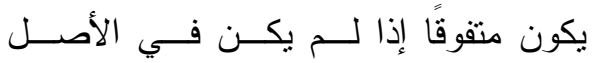

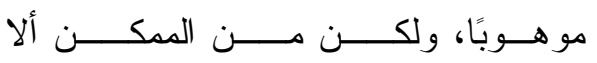

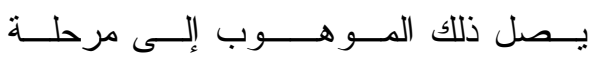
تيرمان، ودر اسة هولنجورث، ويلاحظ أن كل وخل دراهـ

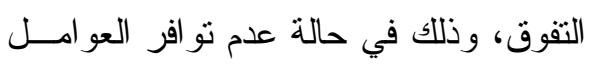

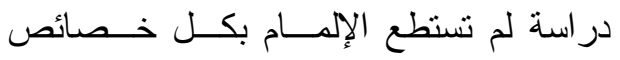

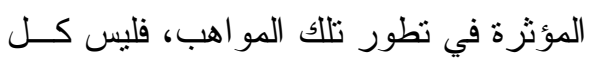

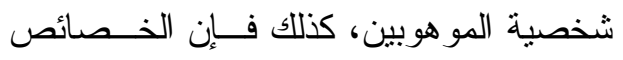
المميزة للمو هو بين لا تعنى أنها موجودة لديهم

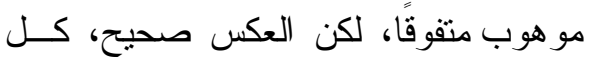
متفوق موهوب في الأصل. وغير موجودة لدى التلاميذ العاديين، ولكنهــــا

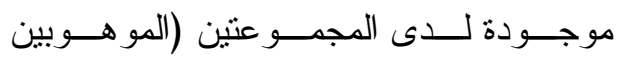

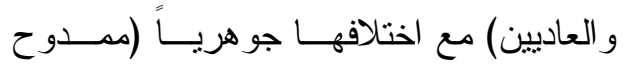

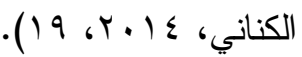

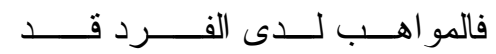

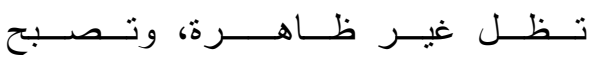

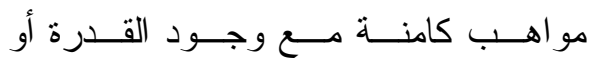
الاستعداد، وهذا ما فسره جانييه لانخفــاض ولض

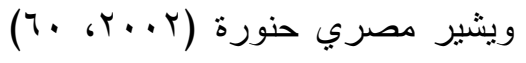

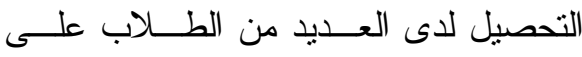

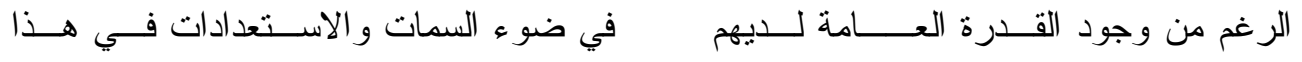


و الفنون البصرية أو الأدائية، و القدرة الــنفس حركية).

كما فضل رينزوللي استخدام مصطلح

السلوك الموهوب بدلًا من الطالب الموهوب،

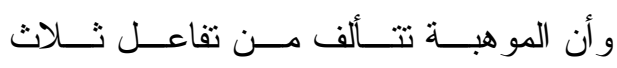

خصائص، هي (قدرات عقلية فوق المنوسط،

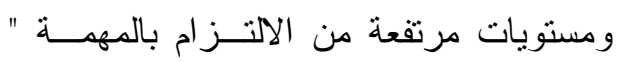

الدافعية"، ومستويات مرتفعــة مــن التفكيـــر

الابداعي) و يستطيع الموهوبــون اســـتخدام

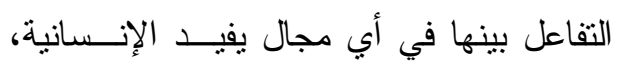

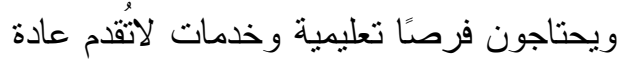

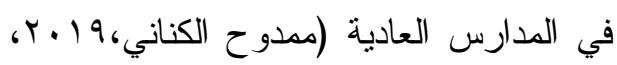

1) م الجدول الآتي يوضح تلك المؤشر ات:
السياق إلى المكونات الأساسية التي ينبغــي

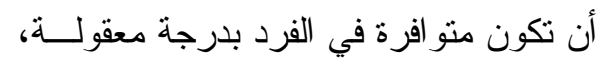

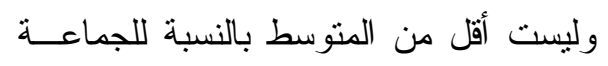

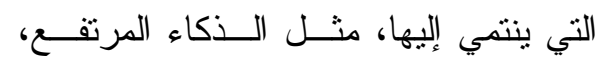

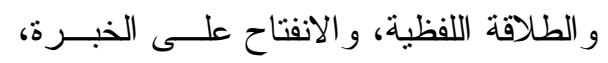

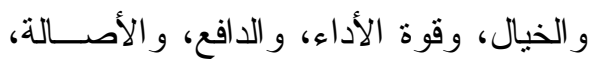

$$
\text { و الغموض .... إلخ وصن الخدان }
$$

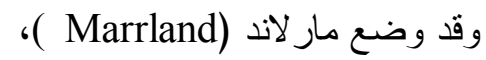

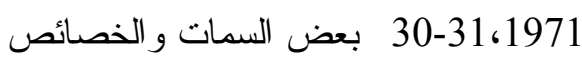

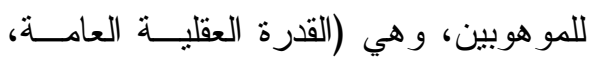

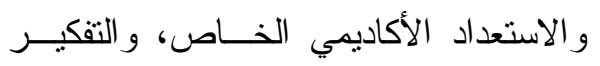

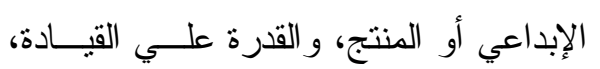

جدول (1) مؤشرات للموهبة من وجهة نظر رينزولي

\begin{tabular}{|c|c|c|c|}
\hline الابتكارية & & الالتز ام بالمهمة & قرة فوق المتوسط \\
\hline تفكير معقد. & & - انتباه طويل المدي. & ذكاء فوق المتوسط. \\
\hline إدر الك العلاقات. & & - د دافعية مرتفعة. & درجات مرتفعة في التحصيل. \\
\hline إصدار أحكام سديدة. & & - التلقائية في أداء المهمة. & قدرة تفوق أقر انه. \\
\hline تقدير الجمال و استحسانه. & & - التركيز لفترة أطول فــي & كم كبير من المفردات اللغوية. \\
\hline الحساسية للمشكلات. & & أداء المهمة. & ذاكرة قوية للخبر ات و الأشياء. \\
\hline القدرة على القيادة الاجتماعية. & & & قدرة عالية على الفهر و الاستيعاب. \\
\hline الاهنمام بالأمور الأخلاقية. & & & ظهور الموهبة في سن مبكرة. \\
\hline
\end{tabular}

يتمتعون بها، فهناك من هو موهوب عقلياً أو الو فئات الطلاب الموهوبين:

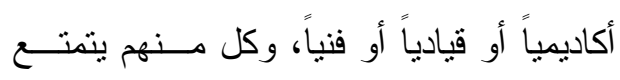
يعتمد نشخيص الطلاب الموهــوبين بخصائص شخصية تميزه عن الآخر، ويمكن

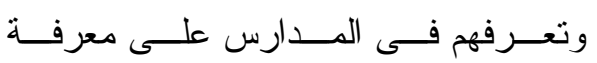
تصنيف الطلاب الموهوبين في الأنواع التالية

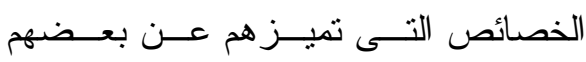

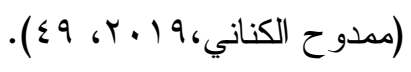

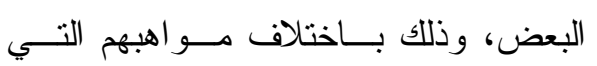


بالآخرين، و القدرة العالية على التعلم (محمود

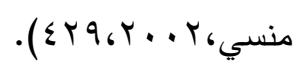

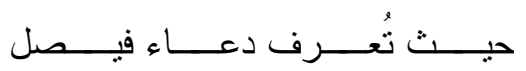

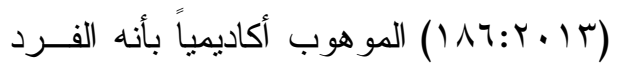

الذى يمتاز بقدرة بارزة، ويرتفع مستوى أدائه

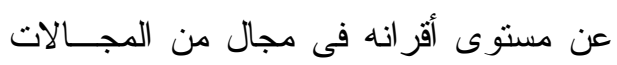

الأكاديمية (التحصيل الدر اسى).

\section{الموهوبون منخفضو التحصيل:}

يعد التحصيل المتدني من المـشكلات

الثائعة لدى المو هوبين، فقد أثنارت الدر اسات

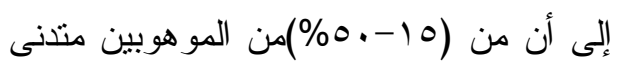

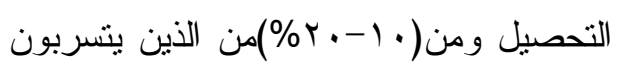

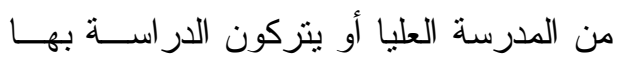
يقعون فى عداد مرتفعـى الــذكاء، كأمنـــال

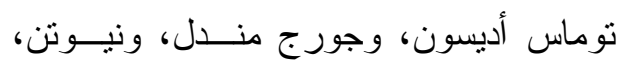

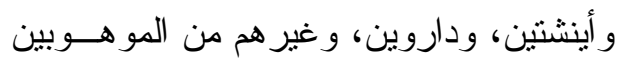

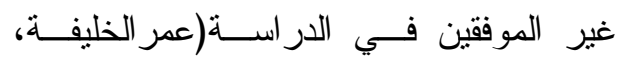
وصلاح الدين عطا الله، 7 . . Y ك ؛ ( ). ومن أهم الخصائص التى ترنبط بتدني التحصيل لدى الطلاب الموهوبين و المتفوقين التقدير المتدنى للــذات الــــى يبــدو بمثابــة الأساس أو المصدر لمعظم مــشكلات تــني التحصيل، ويــرتبط بتــنـي تقــير الــــات سلوكيات أخرى ناجمة عنه أو مر افقـــة لـــه، كالتجنب الدفاعى للواجبات الأكاديمية المهددة

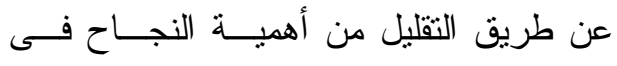
المدرسة والانشغال بنشاطات خارج المدرسة

\section{1 الموهوبون عقليًا:}

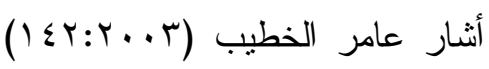

إلى أبرز السمات العقلية التى بتصف بهـــا

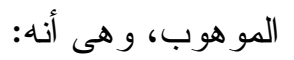

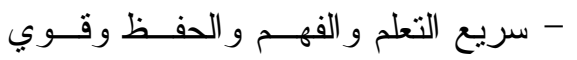

الذاكرة، ودائم الـسؤوال وقــادر علـى لـى

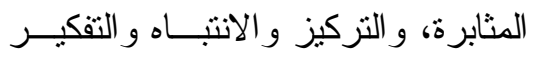

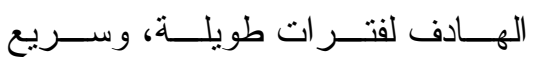

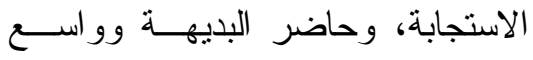

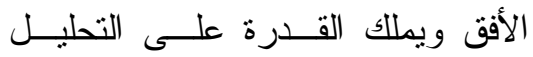

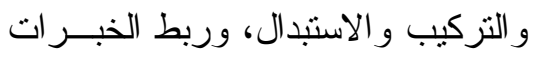
السابقة باللاحقة، و إصدار الأحكام. - محب للاسنطلاع و الفضول العقلى الذى

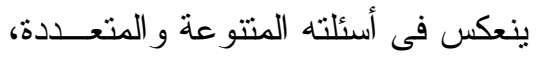

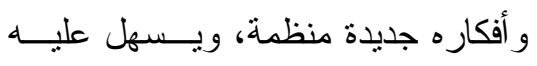
صوغها بلغة سليمة، ويقترح أفكارًا قد يعدها البعض غريبة. - الموهويون أكاديميًا: إن مؤشرات الموهبة الأكاديمية فى لئ

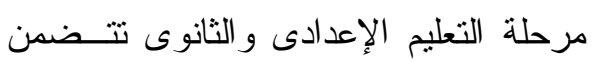

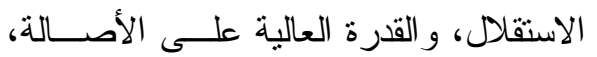

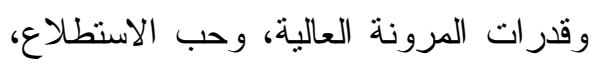

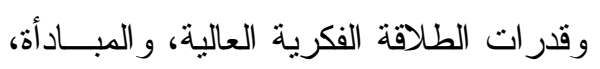
و القدرة العالية على حب المغامرة، و القدرة

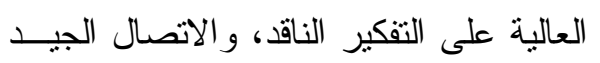


مكتسبة فى مجال معين من مجالات التربيــة

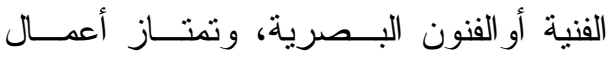

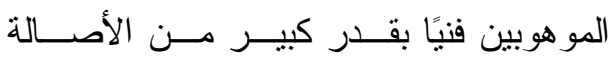

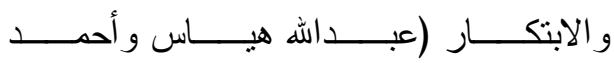
الشباطات،ع ( • r، • (1).

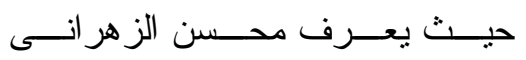

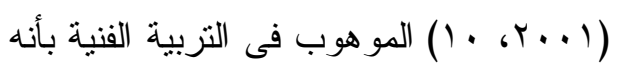

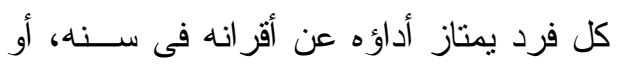

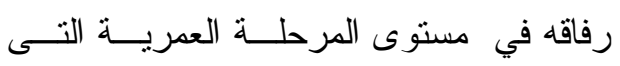
يُصنف فيها، وتتـصف أعمالــه بالأصــالة، و الطلاقة، والمرونة، وتحتوي على أكبر قدر وند من القيم الفنية.

كما أن المو هوب فنيًا يتمتع بالخيــال

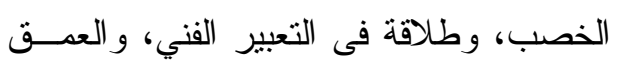

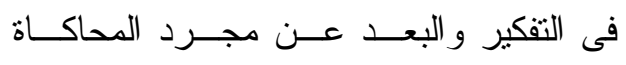

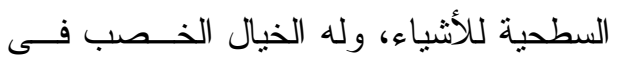

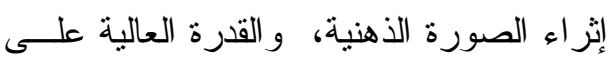

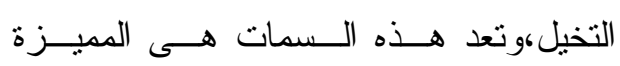
للموهوبين فنيًا أكثر من غير هم الموهوبين في

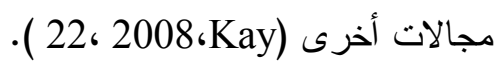

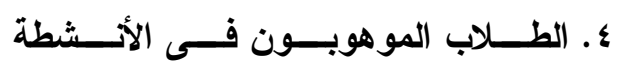

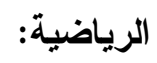

إن الموهبة الرياضية مــن المواهـبـ

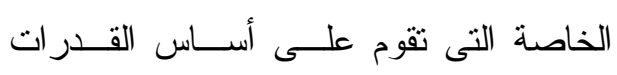

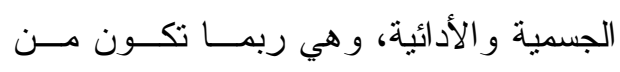

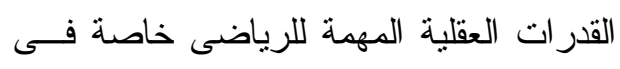

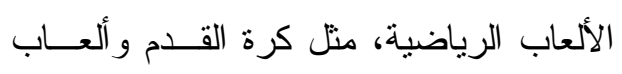

ومهاجمة الأجـــواء الــسلطوية للمدرســة، ووضع أهداف مثالية عليا يصعب تحقيقهــا

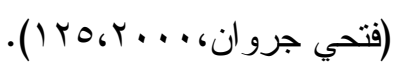

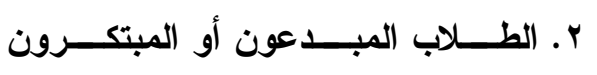
(الاختر اع و الاكتشاف العلمي):

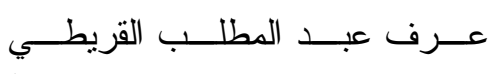

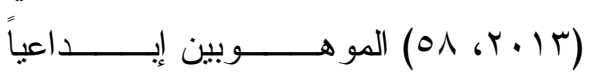
Creativity Gifted

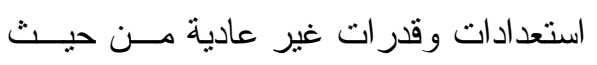
التقكير الإبداعى و الإنتاجى، ويقدمون حلونَ

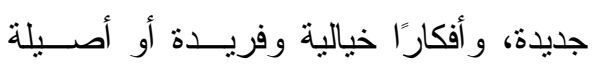
ومنتعبة؛؛ لما يعرض عليهم من مشكلات.

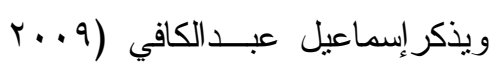
، 107) بعض السمات التي تميز الموهوبين المبدعين أو المخترعين، وهي: - القدرة على الإبـــاع، وإيجــاد الحــل

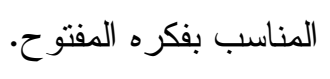

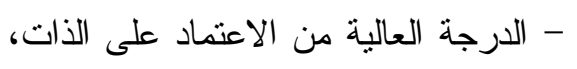

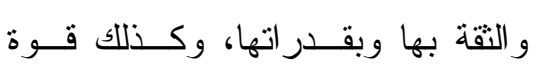

$$
\text { المعتقدات و الأفكار . }
$$

- - المحاولة و الثبات على أن ما يعتقده من أفكار جديدة سوف يكون لها شأن عظيم

$$
\text { يفيد البشرية. }
$$

\section{r. الطلاب ذوو المواهب البصرية الأدائية:}

إن الموهبة الفنية عبارة عن قدرات

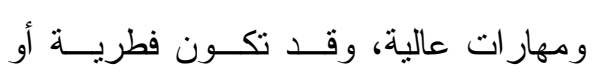


تــنخفض فعاليــة الــــات الأكاديميــة لــــى

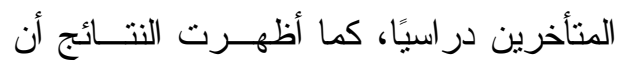
المو هوبين مرتفعي التحصيل أكثر إيجابية في

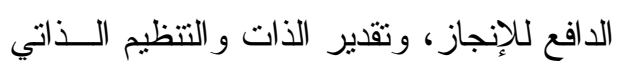

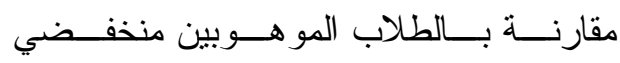
التحصيل.

و أجرت رشئ(Rush)، 2012 در اســـة

هدفت إلى معرفة دور الدو افع في التحـصيل

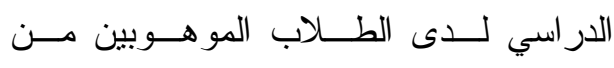

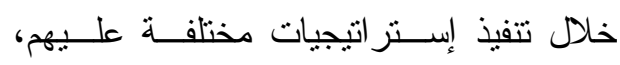

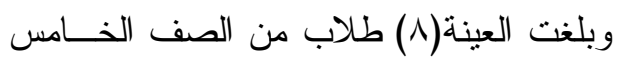

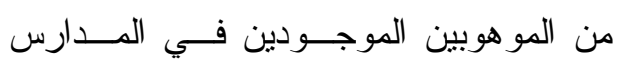

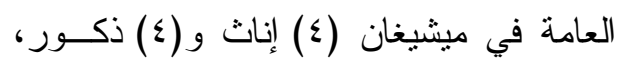

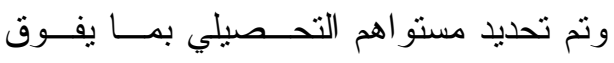

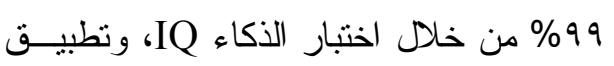

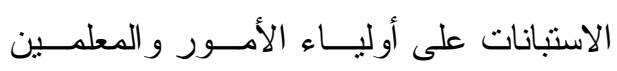
وملاحظة الطلاب وتحليل كافة البيانات، وكان من أهم نتائج الدراسة أن الدو افع هي الحــافز

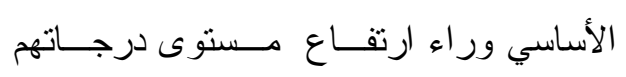

التحصيلية.

كما هدفت در اسة كل من أبوحسامور

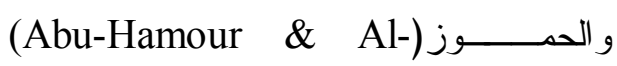
2013،Hmouz التحصيل لدى الطلاب المو هوبين في المرحلة

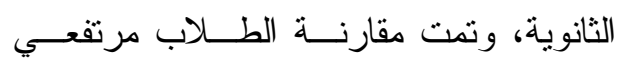
ومتوسطي التحصيل في الدافعيــة و التنظـــيم

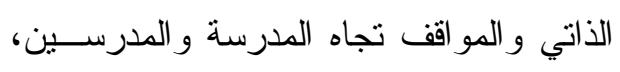

القوى التى لا تعتمد أسـاسًا علــى القــدر ات

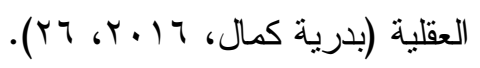

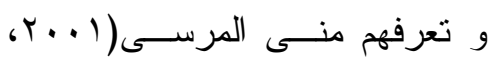

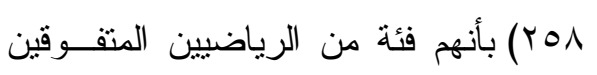

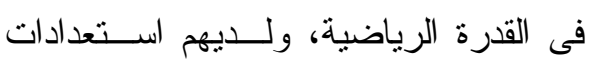
خاصة تؤهلهم لتحقيق أعلى مستوى رياضي ولري يكمن فى نشاط معين.

ويمتاز هؤلاء الطـــلاب بالرشــاقة

و القوى العضلية و القدرة عـــى الاحتمــال

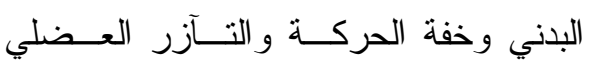

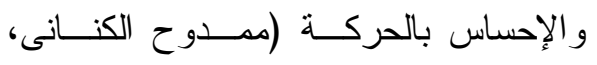
. (17. T... در اسات سابقة مرتبطة

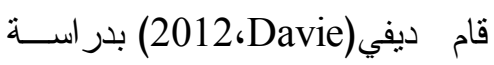

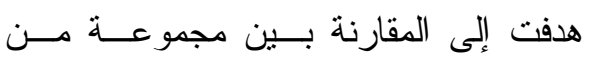

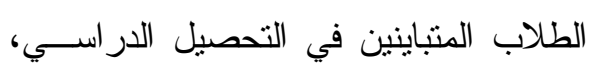
وذلـــك فــي متغيــر ات (الــــافع للإنجــــاز الأكاديمي- فعالية الذات الأكاديمية- التنظيم الذاتي)، وتكونت عينة الدراسة من (^乞V)

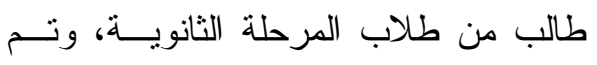
تصنيف الطلاب إلى (مو هو بين - متفــوقين عقليا- متأخرين در اسيًا- مو هوبين مرتفعي لهي

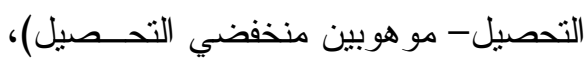

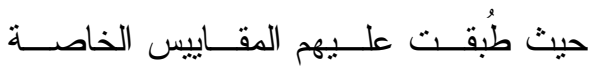
بمتغير ات الدر اسة، وتوصلت النتائج إلى أن

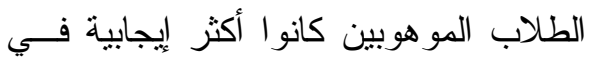

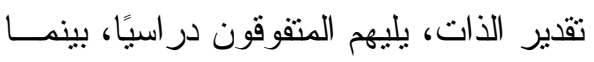


تبعها مر اجعة شاملة لتحديد الأفكـار العامـــة المشتركة، وتوصلت الدراسة إلى وجود ثناثة عو امل مشتركة أسهمت في ضعف وثن التحصيل الدر اسي لدى الموهوبين، وهي (نقص التحفيز

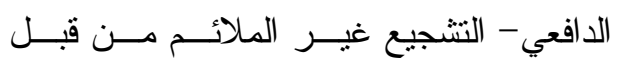

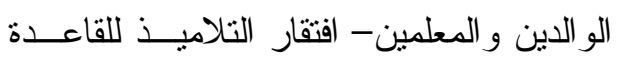
المعرفية أو المهارات المعرفية الأساسية). وأجرت سميحان الرشـبدي (r. V (Y) دراسة هدفت إلى الكثثف عن العلاقــة بـين

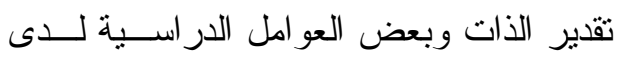
الطلاب الموهوبين بمحافظة الإحساء، وأيضًا الكثف عن الفروق بين الذكور و الإناث فــي

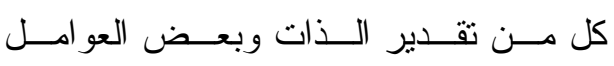
المدرسية، وتكونت عينة الدر اسة من (T؟ ا )

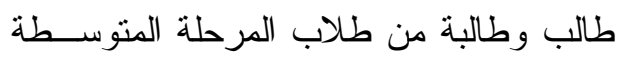
بإدارة التعليم بمحافظة الإحساء بو اقــع (OV)

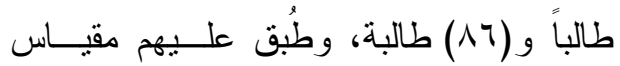

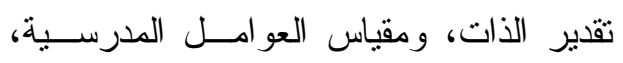

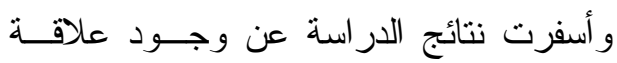

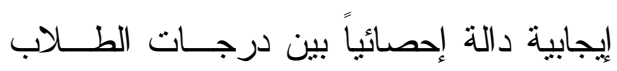

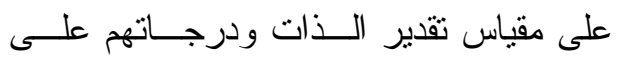
مقياس العو امل المدرسية، وأيضاً وجود فروق ودئ

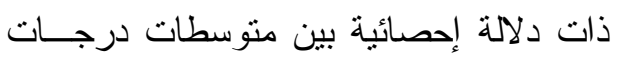
الطلاب و الطالبات على مقياسي تقدير الــــات

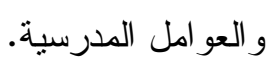

وكانت العينة(9V ( ) طالــب مــن مدرســة ثانوية للموهوبين في إستر البا، وطُلب مسن مُن

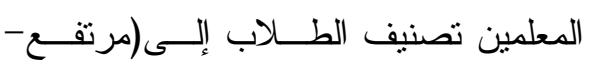
منوسط- منخفض) التحصيل مـن حيــث

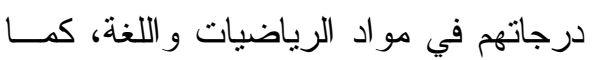

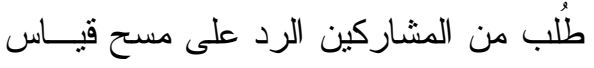
الخصائص الثخصية الخاصة بهم، وتـشير النتائج إلى فروق ذات دلالة إحصائية بـين الدو افع الداخلية و الخارجية لدى الموهــــــين باختلاف فئاتهم (مرتفع- متوسط - منخفض)

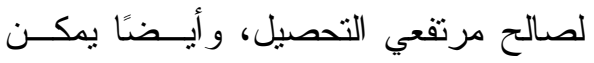
استخدام الدافعية للتمبيز بين أداء (الذكور الإناث). و واســــتهدفت در اســـــة مـــــادوكس Maddox (M)،2014 معرفة أسباب معانــاة

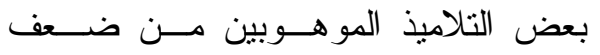

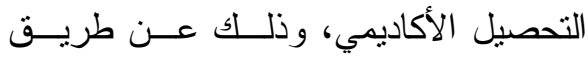

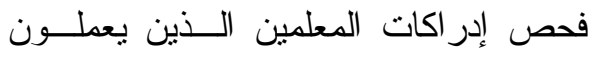

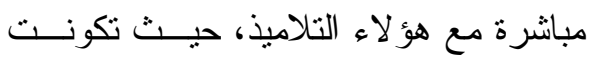

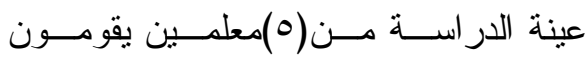
بالتدريس لتلاميذ الصف الر ابع و الخــامس الابتدائي، حيث استخدمت الدر اسة المقابلات الفردية التي تم تسجيلها على شر ائط، وتـــ تجميع معلومات المعلمين حــول خبــر اتهم

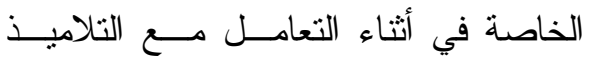
المو هوبين منخفضي التحصيل، وتم تحليـلـل

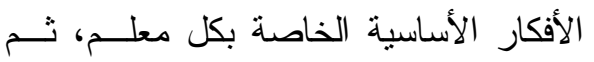


الثانوية بمدارس محافظة الدقهليــة(؟ § ) مــن

الإجرايات اليدانية للدراسة:

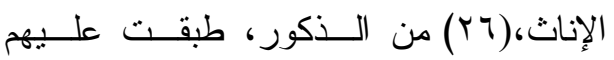

أولاًا : منهج الارسة

أدوات الدراسة بهدف حسـاب الخــصائص الإنس

المنهج المستخدم فى الدراسة الحالية

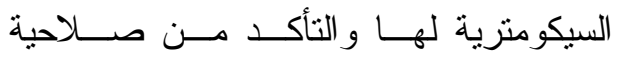

هو المنهج الوصفى، حيث يتم إيجاد العلاقة

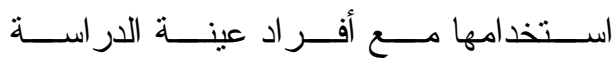

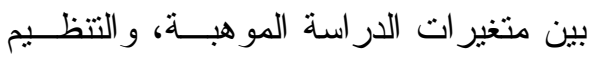

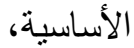

ب. عينة الدراسة:

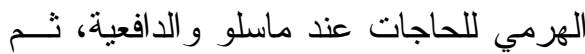

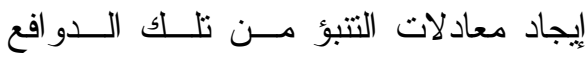

تكونت عينة الدراسة من(ب • () طالبًا

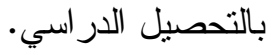

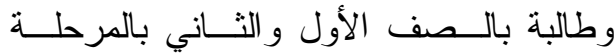

ثانياً: أدوات الدراسة

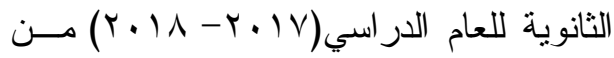

أ. عينــــة تجريــــبـ الأدوات لحــــــاب

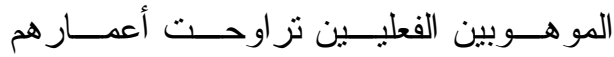

خصائصها السيكومترية:

بين(10 - 11 ) كما بالجدول الآتي :

تكونـــت عينــــة تجريـــبـ الأدو ات

من(• •) طالبًا وطالبة من طلاب المرحلـــة

\begin{tabular}{|c|c|c|c|c|c|c|c|c|}
\hline المجموع & الألكبابة في & وسينما & واختشاف & كتبابة & غناء & موسيقي & ونحت & النوع \\
\hline V) & 1. & IV & . & 1 & 14 & 11 & 19 & أنثي \\
\hline rr & $r$ & $r$ & 7 & $\varepsilon$ & $\varepsilon$ & 1 & 11 & ذكر \\
\hline $1 . r$ & $1 \pi$ & $r$. & 7 & 0 & IV & IT & $r$. & المجموع \\
\hline
\end{tabular}

وكان الهدف منها تصنيف الطلاب الموهوبين

ثالثًا: أدوات الدراسة:

حسب نوع كل موهبة.

1- استبانة إنجاز الموهبة الإبداعية

تتكون هذه الاستبانة من(9)أبعاد(الرسم

استخدمت الباحثة اسـتبانة إنجــاز

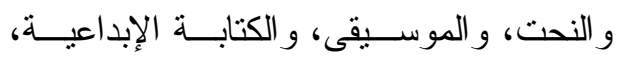

المو هبة الإبداعبة من إعداد شيلي كارسون

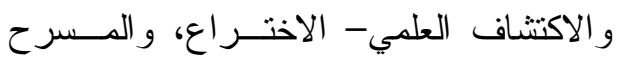

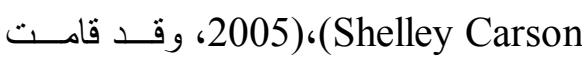

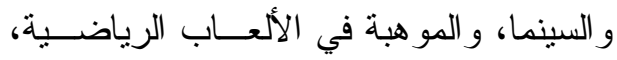

الباحثة بترجمة الاستبانة وعرضــــا علــي

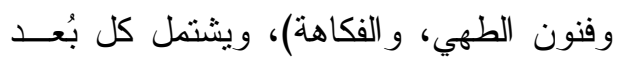

بعض المتخصصين فى اللغة الإنجليزيــة،

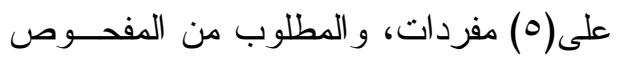

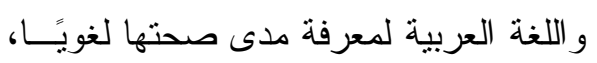

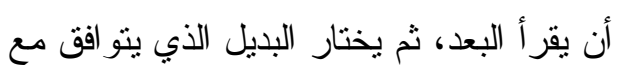


الاسنبانة (V) أبعاد نتكون منها الاسنبانة فـى

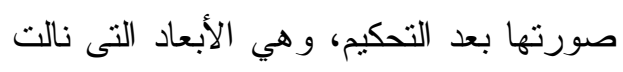
نسبة اتفاق ه^\% فأكثر.

r - مقياس السمات السلوكية للموهوبين

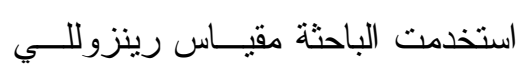

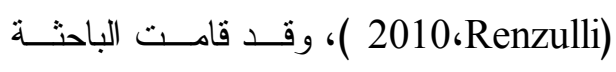

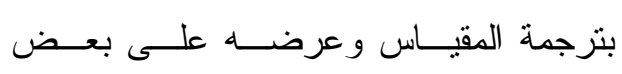
المتخصصين فى اللغة الإنجليزية، ثم عرضه وترضه

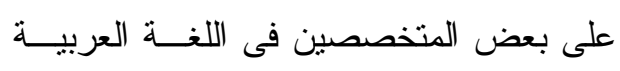

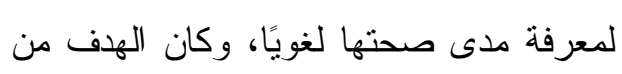
ذلك المقياس هو معرفة الخصائص التي تمبز كل نوع من انواع المو اهب. ويتكون هذا المقياس من( ال I)مفردة

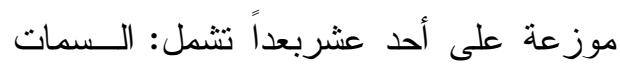

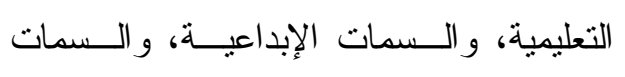

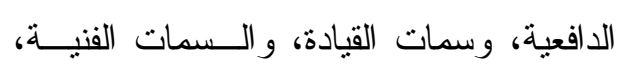

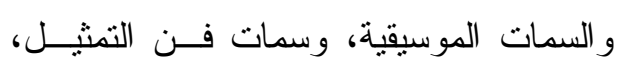

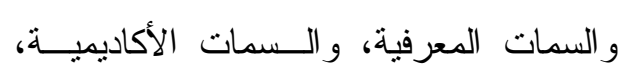

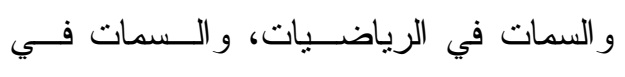

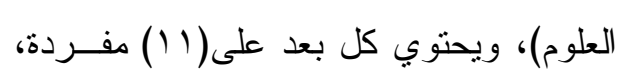
ويحدد المفحوص مدى انطباق المفردة عليــــ

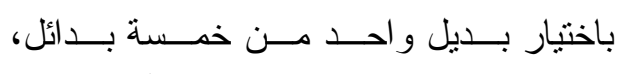

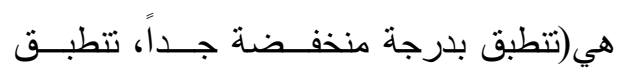

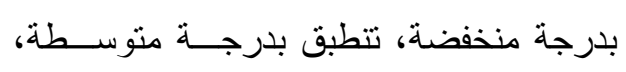
تتطبق بدرجة مرتفعة، تتطبق بدرجة مرتفعة

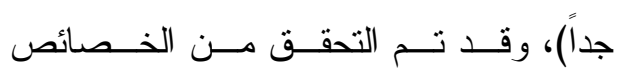
السيكومترية لهذا المقياس فى بيئته الأصلية.

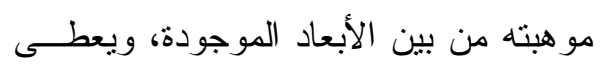

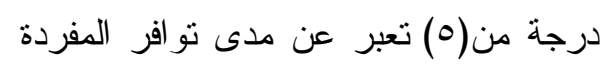

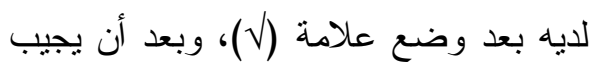
المفحوص ويعطى درجة تقدير ذانية علـي بـي

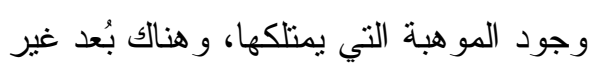

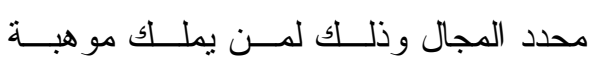

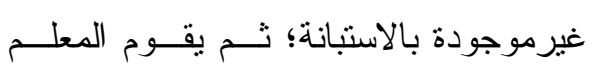

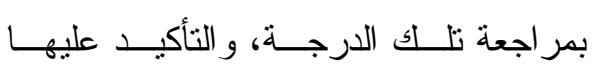
بالثباتأو النقصـان بلما يتو افر لديه من بيانــات وسجلات يمتلكها عن هؤلاء الطلاب. تم عرض الاستبانة على مجموعــة من المحكمين المتخصصين فى علم الــنفس التزبوى، و الصحة النفسية فى بعض كليات

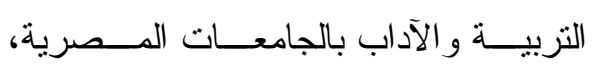

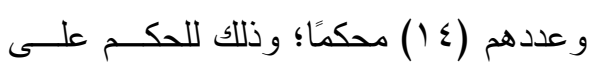
تللك العبار ات من حيث(مدى مناسبة الأبعاد

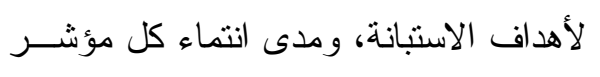
وملاعمة صياغته اللغوية، ومدى ملاعمـــة المؤشر ات للأبعاد، ومدى ملاعمة المفردات لطلاب الثانوية العامة، بالإضافة إلي تعديل

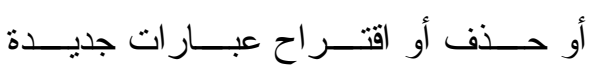
للاستبانة)، وقامت الباحثة بحذف المفردات

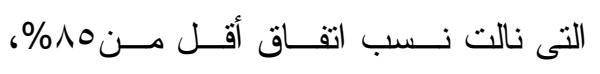
كالفكاهة، وفنون الطهي، حيث إنه يجب ألا

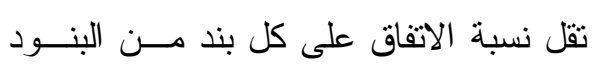

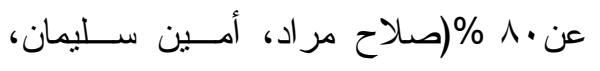

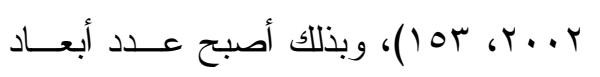


بعد من أبعاد المقياس، و علي هــذا لـــــيُقــر الإتساق الداخلي حذف أي مفردة من مفردات

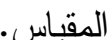

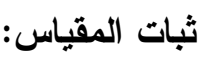

تم تطبيق المقياس على عينة تجريــب

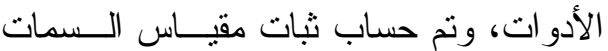

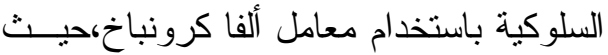
أن قيمة ثبات أبعاد المقياس نز اواحــت بــين

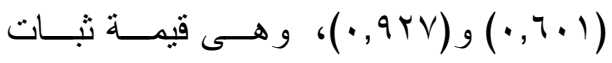
مقبولة إحصائيًا، كما يتضح أن قيم معساملات الثبات التي ينم الحصول عليها عند حذف أي مفردة من مفردات المقياس تقل بدرجة بسيطة

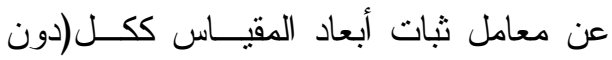
حذف أي مفردة) أو تساويه، مما يدل على أن لن جميع مفردات المقياس ثابتة، وتم حساب ثبات

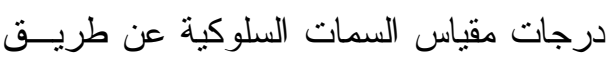
معادلة سبيرمان بر اون للتجزئسة النـصفية، حيث أن قيمة ثبات أبعاد المقياس بعد تصحيح الطول بطريقة سبيرمان بر اون نراواحت بين

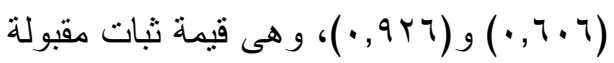

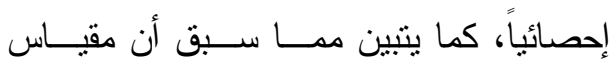

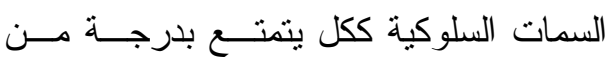

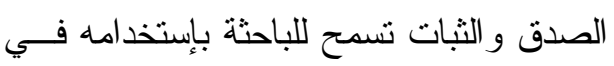

$$
\text { الدر اسة الحالية. }
$$

r-مقياس الدوافع الداخلية والخارجية قامت الباحثة بإعداد مقياس الدو افع، نم تحديد أبعاد المقياس مــن خــلال المــصادر
الخصائص السيكومترية لمقياس الـسمات

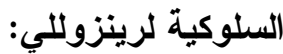

قامت الباحثة بحساب ثبات وصدق المقياس كما يأني: ץ- صدق المحكمين( صدق المحتوى): تم حساب صدق المحكمين من خلال عرض المقياس على مجموعة من المحكمين

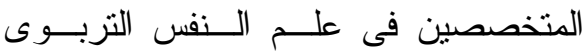
و الصحة النفسية فى بعض كليــات التربيــــة

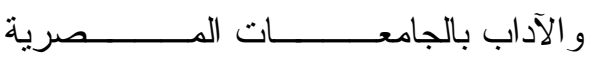
و عددهم( ـ ()محكمًا؛، ونم تفريغ ملاحظات ومقترحات السادة المحكمين، وكانت نـسـب لــان اتفاق الـسادة المحكمــين علــى مفــردات

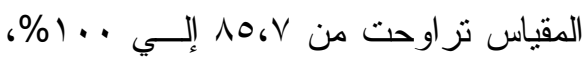
وبذلك لم يتم حذف أي مفردة، ويكون عـدد نـ مفردات المقياس( (Y I)مفردة.

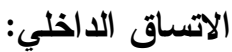

تم تطبيق المقياس على عينة تجريب الأدو ات، وتم حساب معاملات ارتباط درجة

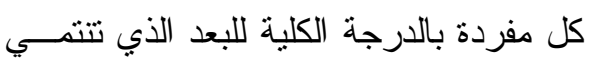
إليه ، وتم حساب معاملات ارتباط درجــة

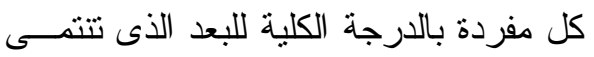
إليه، وتر اوحت جميع قيم معاملات الارنباط

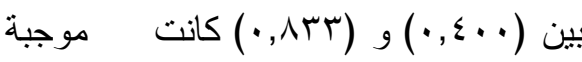

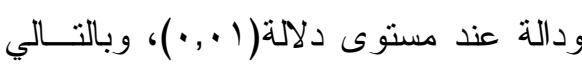
فإن مفردات المقياس تتجه لقياس درجة كل دل 
السادة المحكمين؛ حيث أن هناك (†) مفردات

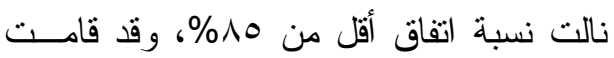
الباحثة بحذف هذه المفردات؛ وبذلك أصــبح ندان عدد مفردات المقياس( ؟Y) مفردة ينكون منها

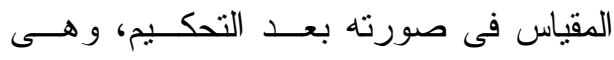
المفردات التى نالت نسبة اتفاق هیر\% فأكثر .

$$
\text { الصدق التلازمى }
$$

تم التحقق من صدق المقيــاس عـنـ طريق حساب العلاقة الارتباطبة بين درجات

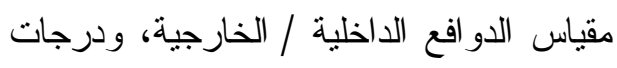

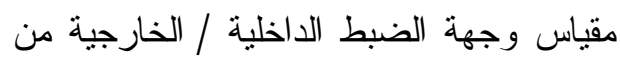

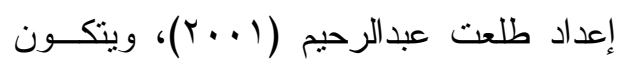

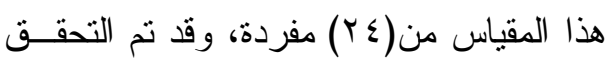
من الخصائص السيكومنزية لهذا المقياس، فقد نم تطبيق المقياس على عينة تجريب الأدوات،

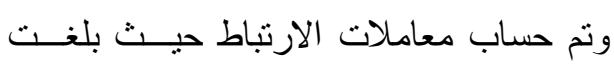

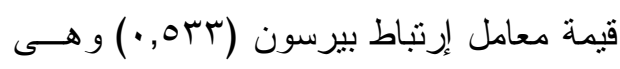

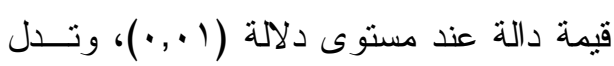

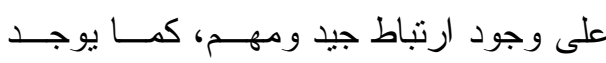
إرتباط دال إحصائيًا بين درجات الطلاب في ودي

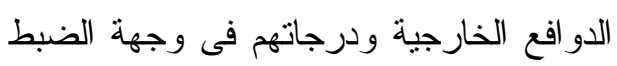

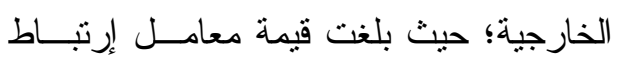

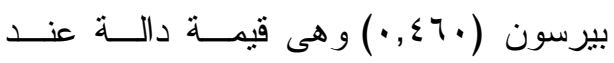

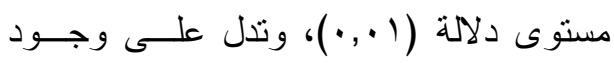

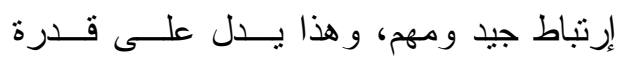

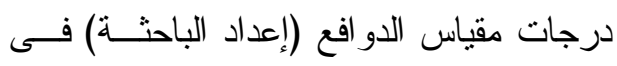

السابقة، وقد استطاعت الباحثة إبــتخلاص أبعاد الدافعية إلي بعدين يتمنلو ا في (الدوافع

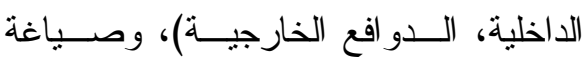
مجمو عة مفردات تتتمى لكل بُعد من البعدين

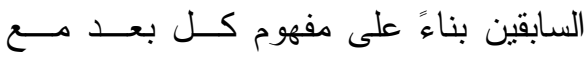

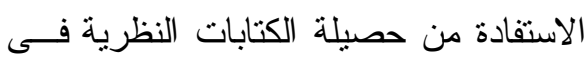
مجال الدوافع، وتكونت صورة المقياس من

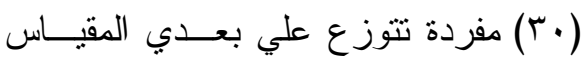
(الدو افع الداخلية وتتكون من(10) مفــردة)

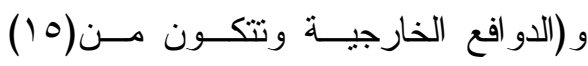
مفردة)؛ ويحدد الطالب مدى إنطباق المفردة عليه باختيار بديل و احد من خمـسـة بـــــائل هي (تتطبق بدرجة منخفضة جدًا، تتطبـق

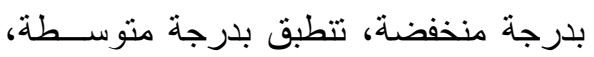

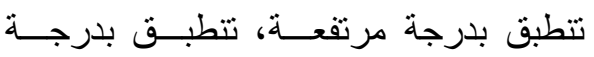
مرتفعة جدًا). الخصائص السيكوميترية لمقياس الــدوافع الا اخلية و الخارجية: قامت الباحثة بحساب ثبات وصدق المقياس كما بأتي

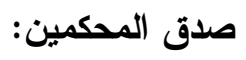
نم حساب صدق المحكمين من خلال المقياس على مجموعــة مــن المحكمـين المتخصصين فى علــم الــنفس التربــوى و الصحة النفسية فى بعض كليــات التربيـــة و الأداب بالجامعات المصرية و عددهم (ع ( )

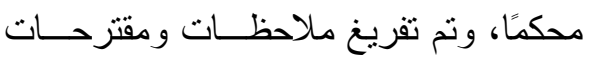


حذف أي مفردة) أو تساوية، مما يدل على أن جميع مفردات المقياس ثابتة.

و استخدمت الباحثة معادلة سـبيرمان

براون للتجزئة النصفية، وبحسـساب معامـلـل الارتباط بين رتب المفردات الزوجية، ورتب

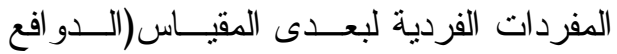

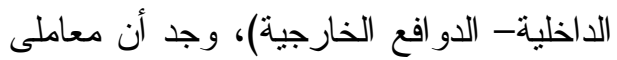

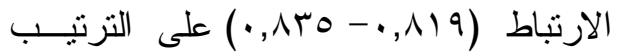
وبالتعويض فى معادلة التتبؤ لسبيرمان براون

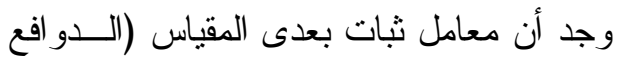

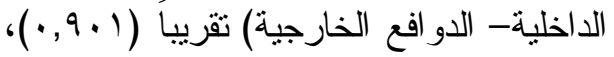
وتنين أن مقياس (الدو افع الداخلية والخارجية) ككل يتمتع بدرجة من الصدق و الثبات تـسمح للباحثة باستخدامه في الدر اسة الحالية. ـ - مقياس التنظيم الهرمي للحاجات عنـــ ماسلو.

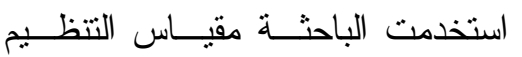
الهرمي للحاجات عند ماسلو ، وهو من إعداد (ممدوح الكناني، وتعديل أســماء مــصطفي، وهئ $(r+1)$

تكونت صورة هذا المقياس مـن(؟)م) مفــردة تتــوزع علــي ســبعة أبعــاد كمــــا يلي:(الحاجات الفسيولوجية، و الحاجــة إلــى لــ الأمن، و الحاجة إلى الحب والانتماء، و الحاجة

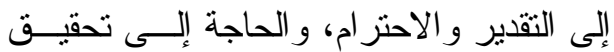

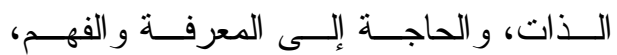

$$
\text { و الحاجات الجمالية). }
$$

النتبؤ بالأداء الحالى على محك آخر تستخدم فيه السمة موضع الاهنمام.

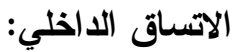
تم تطبيق المقياس على عينة تجريب الأدوات، وتم حساب معاملات ارتباط درجة كل مفردة بالدرجة الكلية للبعد الذي نتتمــي إليه ، وتم حساب معاملات ارتباط درجــة كل مفردة بالدرجة الكلية للبعد الذى تتتــى إليه، فكانت جميع قيم معساملات الارتبــاط

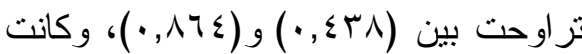

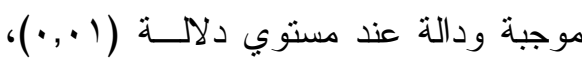
وبالتالي فان مفردات المقياس تتجه لقيــاس درجة كل بعد من أبعاد المقياس، وعلي هذا

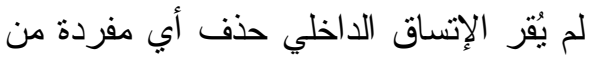
مفردات المقياس.

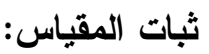
تم تطبيق المقياس على عينة تجريب الأدوات، وتم حساب ثبات مقياس الــدو افع لـع

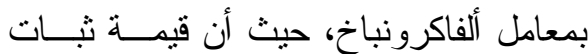

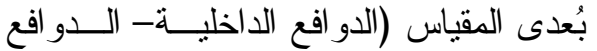

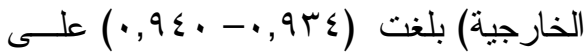

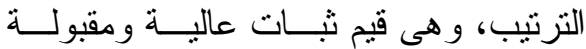
إحصائياً، كما يتضح أن قيم معاملات الثبات

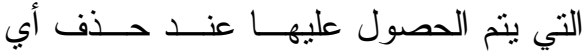
مفردة من مفردات الأبعــاد تقــل بدرجـــة بسيطة عن معامل ثبات البعـــ كــل(دون 


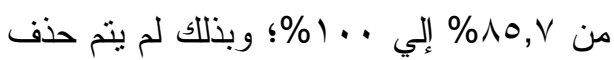

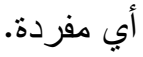
الإخساق الداخلي

نم تطبيق المقياس على عينة تجريــب

الأدو ات، وتم حساب معاملات ارتباط درجــة

كل مفردة بالدرجة الكلية للبعد الذي تتنمي إليه

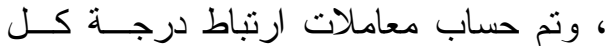
مفردة بالارجة الكلية للبعد الذى تتنمى إليــه،

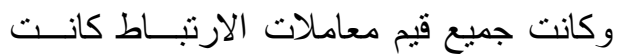
موجبة ودالة عند مستويدلالة (1.,.•)، حيث

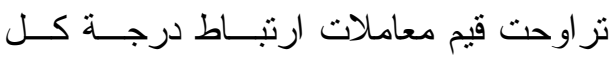

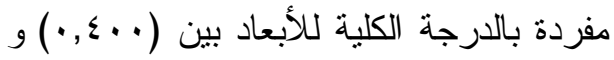
مما يدل على وجود علاقة جيــدة (•VV) ومهمة بين درجة كل مفردة و الدرجة الكليــة

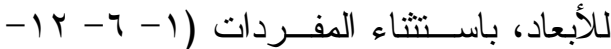

$\left.-\Sigma V-\Sigma T-\varepsilon r-r_{0}-Y\right)-19-1 \leqslant$ $-V V-V 7-V \leqslant-79-70-01-\leqslant 9$ فكانت قيم معاملات الارنباط فيها

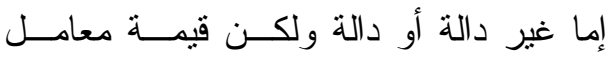

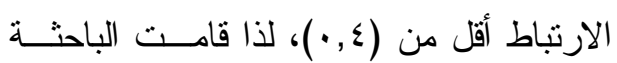
بحذف تلك المفردات من المقياس فى النطبيق النهائى وهى (9 (1) مفردة، وبذلك يصبح عدد مفردات المقياس (70) مفردة.
ويحدد المفحــوص مــــي انطبــاق

المفردة عليه باختيار بديل واحد من خمسسة بدائل، هى (تنطبق بدرجة منخفضة جـدًا، لئل

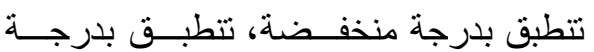

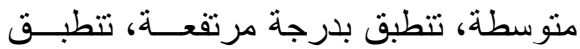
بدرجة مرتفعة جدًا)، وقد نم التحقـق مسنـ الخصائص السيكومترية لهذا المقياس فـى لـى لهـ

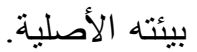
فقد كان يجيب الطالب عن المقيــاس بقلمين مختلفين اللون(أزرق - أحمر)، حيث

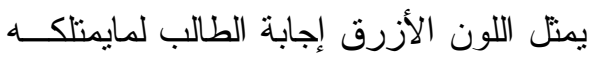

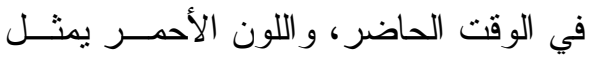

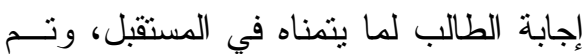

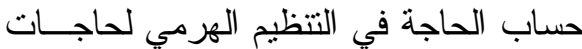
ماسلو عن طريق المعادلة الآتية: الحاجة = المستوى المأمول- المستوى الفعلي(ممدوح

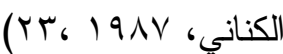
الخصائص السيكومترية لمقياس التنظــيم الهرمي للحاجات عند ماسلو: قامت الباحثة بحساب ثبات وصدق المقياس

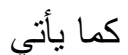

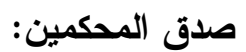

تم حساب صدق المحتوى من خلال عرض المقياس على مجموعة من المحكمين

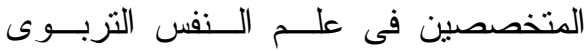

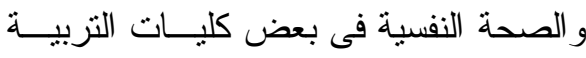

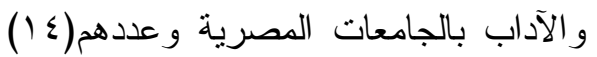
محكمًا، يتضح أن مفردات المقياس نز اوحت بـ 
ويتكون في صورته النهائية من(70) مفردة.

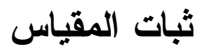

الأساليب الإحصائية المستخدمة في الار اسة

نم تطبيق المقياس على عينة تجريب

1- معامل ارتباط سبيرمان.

الأدوات، وتم حساب ثبات مقياس التنظــيم

r- تحليل الانحدار المتعدد.

وصف نتائج اختبار الفرض الأول وتفسيرها:

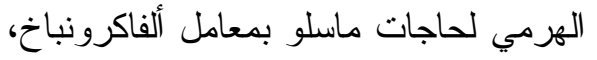

حيث أن قيمة ثبات أبعاد المقياس نراواحت

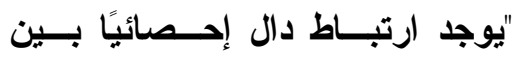

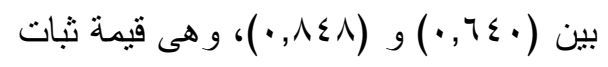

التحصيل الأكاديمى الطلاب الموهوبين مـن التبن

مقبولة إحصائياً، كما بتضح أن قيم معاملات

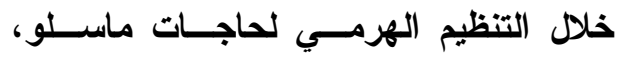

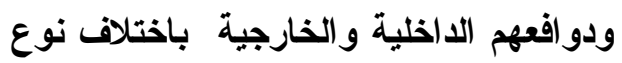

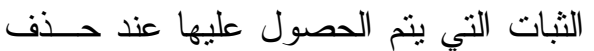

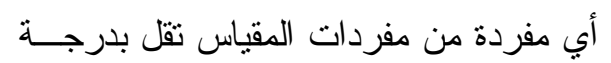

بسيطة عن معامل ثبات أبعاد المقياس ككل الموهبة ".

و لاختبار هذا الفرض، قامـــت الباحثنـة

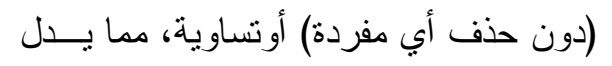

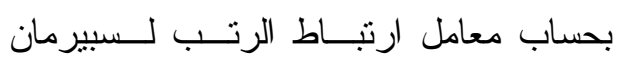

على أن جميع مفردات المقياس ثابتة.

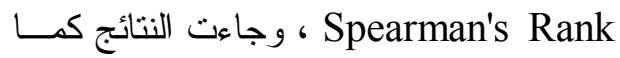

يتبين مما سبق أن مقياس (ماســلو )

يوضحها جدول(اس) وذلك على النحو الآتى:

ككل يتمتع بدرجة من الصدق و الثبات تسمح

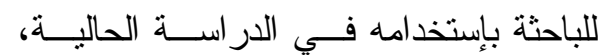

جدول (1) : قيم معاملات معامل ارتباط الرتب لسبيرمان بين التحصيل الأكاديمى للطلاب

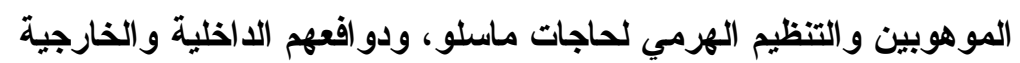

\begin{tabular}{|c|c|c|c|c|c|c|c|}
\hline \multicolumn{7}{|c|}{ التحصيل } & \multirow{3}{*}{ المتغير } \\
\hline \multicolumn{7}{|c|}{ نوع الموهبة } & \\
\hline 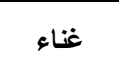 & رياضية & اكتشى & ابدابية & موسيقى & مسرح & رسم & \\
\hline 0.037 & -0.199 & -0.429 & -0.667 & 0.183 & -0.046 & -0.096 & الحاجات الفسيولوجية \\
\hline-0.078 & -0.077 & 0.543 & -0.410 & -0.347 & -0.304 & -0.352 & الحاجة إلى الأمن \\
\hline-0.012 & 0.110 & -0.174 & 0.051 & -0.296 & -0.212 & -0.165 & الحاجة إلى الحب و الانتماء \\
\hline 0.324 & 0.025 & 0.232 & -0.400 & 0.086 & -0.151 & $-0.534 * *$ & الحاجة إلى التقدير و الاحتر اج \\
\hline 0.472 & -0.078 & $-0.880^{*}$ & -0.103 & -0.134 & -0.432 & -0.071 & الحاجة إلى تحقيق الذات \\
\hline 0.348 & -0.444 & 0.600 & -0.791 & -0.459 & -0.014 & -0.145 & الحاجة إلى المعرفة و الفهر \\
\hline-0.261 & -0.457 & 0.741 & $0.975 * *$ & 0.025 & 0.086 & -0.043 & الحاجات الجمالية \\
\hline $0.683 * *$ & $0.647^{*}$ & $-0.943 * *$ & 0.500 & 0.251 & $0.462^{*}$ & $0.477 * *$ & دو افع داخلية \\
\hline$-0.626^{* *}$ & -0.541 & 0.441 & $-1.000 * *$ & -0.156 & $-0.475^{*}$ & $-0.560 * *$ & لدو افع خارجية \\
\hline
\end{tabular}

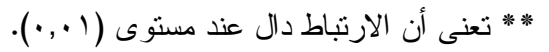

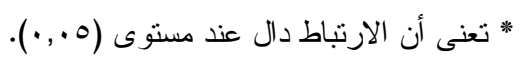


تقدير الذات يسهم فــي توظيــــ المهــار ات

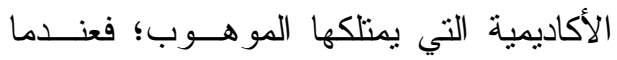

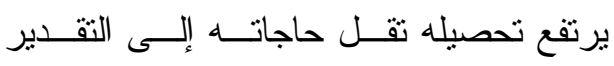

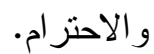

كما أن موهوب الرسم حينما بـشعر

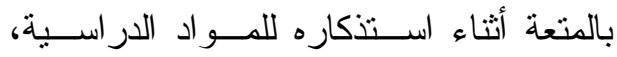
ويبحث عن المعلومات من أجل زيادة خبر اته، يستطيع توظيف قدر اته و امكاناته مــن قــدرة على الملاحظة، و إدر الك للعلاقات، و إضــفاء

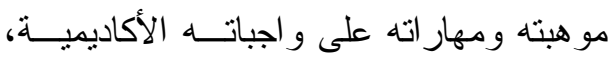
ومقتتياته الدر اسية، وتوضيح العلاقــات بــين

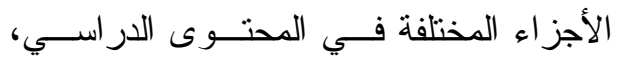
وربط العناصر بعضها ببعض، وو إيجاد أوجه الثبة و الإختلاف، و إدر الك الرئيسي و الفرعي،

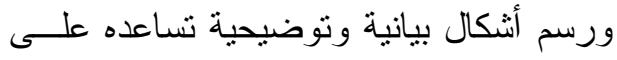
الفهم و الاستذكار الجيد يؤدي ذلك إلى ارتفاع تحصيله. - توجد علاقة طرديــة بـين التحـصيل

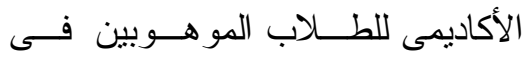

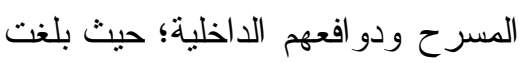
قيمة معامل ارتباط سبير مان (0.462)

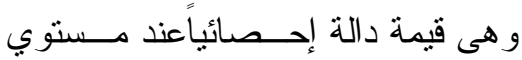

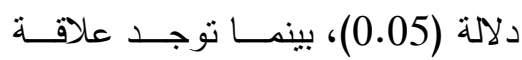

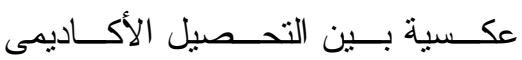

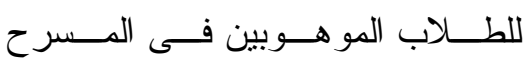
ودو افعهم الخارجية؛ حيث بلغت قيمسـة

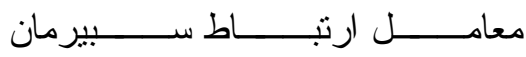

\section{يتضح من نتائج جدول ( ) ما يلى:}

- - توجد علاقة طردية بـين التحـصيل

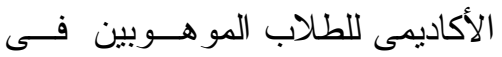

الرسم ودو افعهم الداخلية؛ حيث بلغت

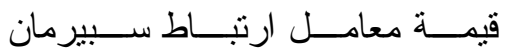

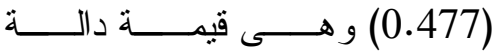

إحصائيًاعند مستوي دلالـــة (01.0)،

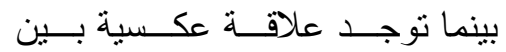

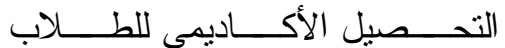

المو هوبين فى الرسم وحاجاتهم إلـى

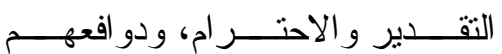

الخارجية؛ حيث بلغت قيمتى معامـلـ

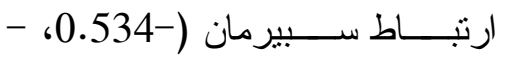

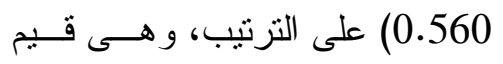

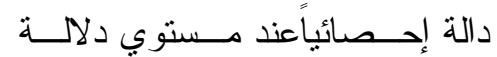

.$(0.01)$

وتُفسر الباحثة ذلك بأن الحاجة إلـى

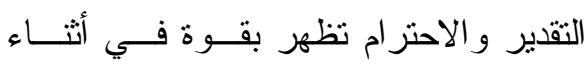
مرحلة المر اهقة و البلوغ، وهي مــن أكثتـر

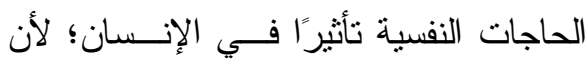
تلبيتها يؤدي إلى شعور المر اهــق بــالقبول الاجتماعي لدى الآخرين، و افتقاده لها يجعله

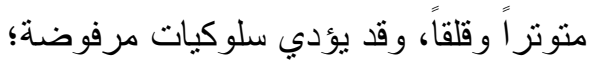

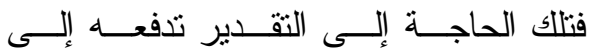

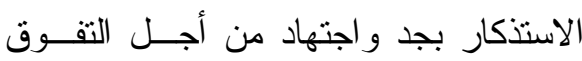
الأكاديمي للحصول على القيمة الاجتماعية، و الاعتر اف به من قبل الأخرين، وكذلك فإن الن النئ 
إحصائياًعند مستوي دلالـــة (0.01)،

بينما توجد علاقة عكسية تامسـة بـين التحصيل الأكاديمى للطلاب الموهوبين

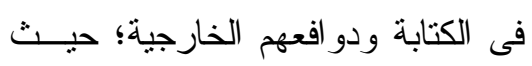
بلغت قيمة معامل ارنباط سبيرمان (-)

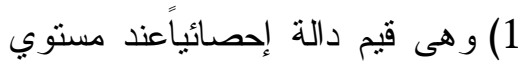
دلالة (0.01).

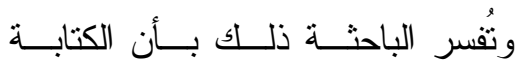
الإبداعية تتطلب الجمال من أجل تحقيق متعة القارئ فيبذل المو هوب أقصي مالديه لتحقيق

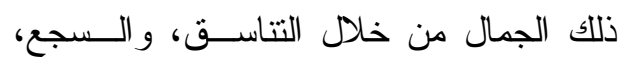

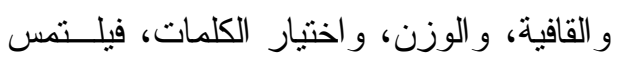

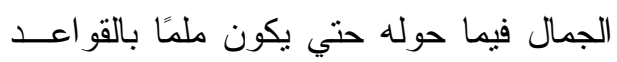

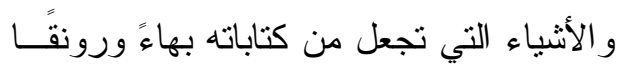
خاصًا به؛ كما أن الكتابة الإبداعية ناثشئة عن

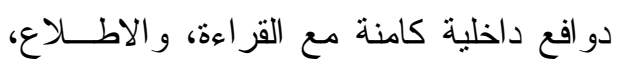

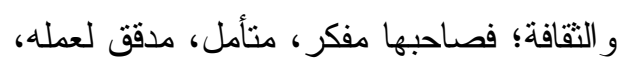

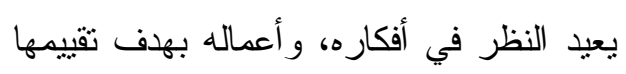
وتظويرها ليس لأجل الآخرين، أو لانتظــار

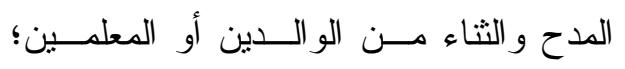

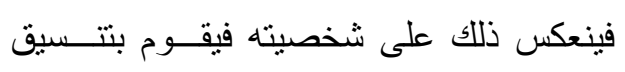

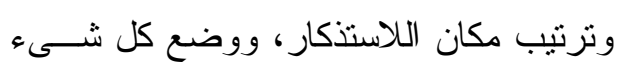
في مكانه داخل حجرته التـي يعـيش فيهـا

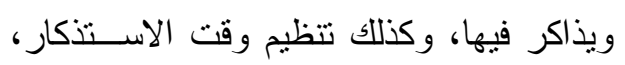

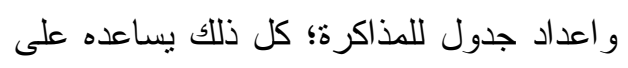

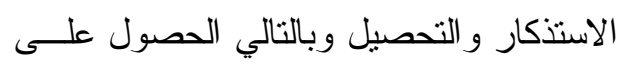

$$
\text { درجات مرتفعة. }
$$

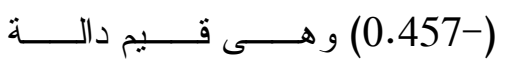
إحصائياًعند مستوي دلالة (0.05).

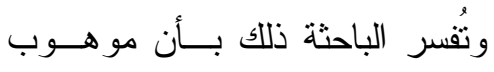

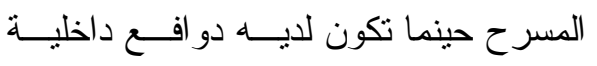

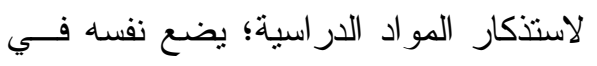

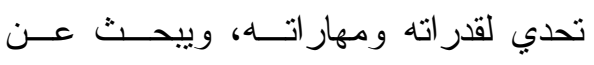

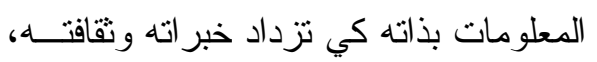
فيستطيع من خلال سماته التي يمتلكها مــن

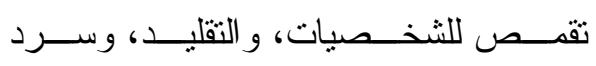
القصص بسهولة وتشويق ان بوظفها أثتــاء استذكار دروسه، فيحول المواد الني يدرسها

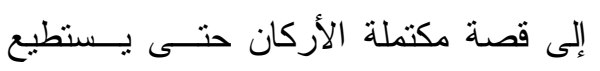
تذكر ها، ويربط بين الثخصيات و التــو اريخ

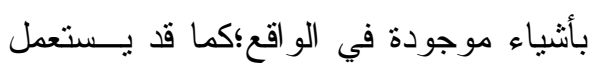

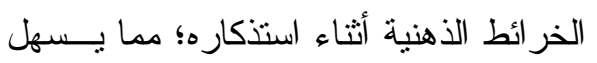
عليه اجنياز المو اد الدراسية بسهولة، ومــنـ ثم يرتفع تحصيله.

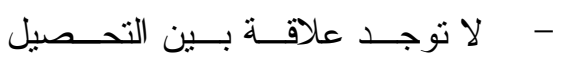

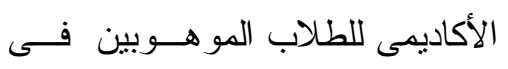
الموسيقى وخصائصهم الأفعية؛ حيث جاءت جميع قيمة معامـل ارتبــاط سبيرمان غير دالة إحصائيًا. - توجد علاقة طردية بـين التحــصيل

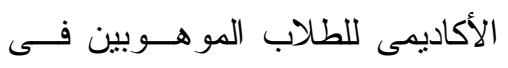
الكتابة وحاجاتهم الجماليــة؛ حيـــث بلغت قيمة معامل ارتباط سـبيرمان

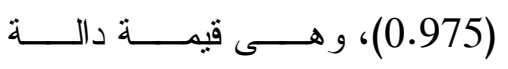




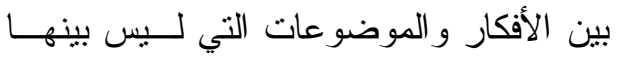

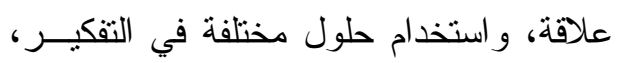
وقدرة على التلاعب بالأفكار، وتطبيق مــاتم تعلمه من قبل، وذللك كله من أجــل إرضــــاء ولطياء

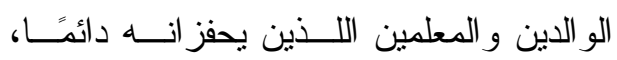

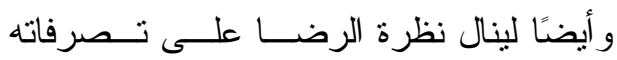
وسلوكياته حتى و إن كانت مغايرة لما يرتضيه

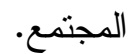
كما أنه كلما ارتقى مو هوب الاكتشاف العلمي بموهبته، وازداد تحصيله؛ كلما كــان

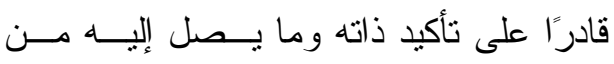

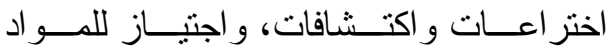
الدر اسية كلما انخفضت حاجاته إلى تحقيــق ذاته.

- توجد علاقة طرديــة بــين التحــصيل

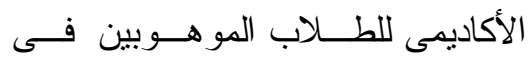
الألعاب الرياضية ودو افعهم الداخليـــة

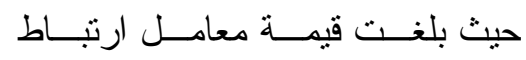
سبير مان (0.647) و هى قيمــة دالـــة إحصائياًعند مستوي دلالة (0.05). وتُفسر الباحثة ذلك بأن النظرة الخطأ

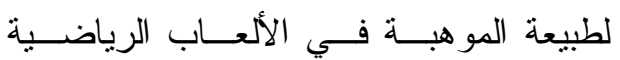
ومايصاحبها من إضاعة الكثير من الوقت في التـريب، وممارســة الأنـشطة الرياضـــية،

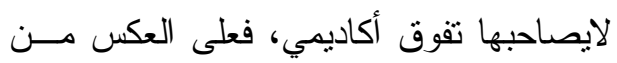

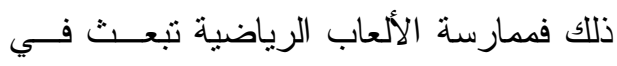
الجسد و العقل القوة و النشاط، وتجعله منيقظً
- توجد علاقة عكسية بــين التحـصيل

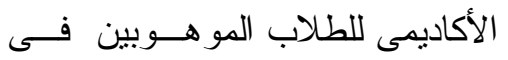
الاكتشافات العلمية وحاجــاتهم إلــى تحقيق الذات، ودو افعهـــم الداخليـــة؛

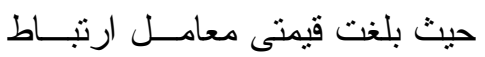

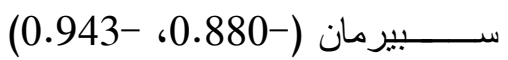

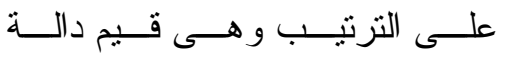
إحصائياًعند مستويى دلالــــة (0.05، 0.01) على الترنتيب. إن سمات مو هوب الاكتثاف العلمي لاتكفي لاستثارة الرغبة لديه للتعلم وازديـاد تحصيله بل قد يصبح مــنخفض التحـصيل

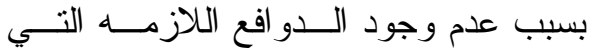
تجعله يذاكر دروسه؛ فيحتاج إلى التوجيــة

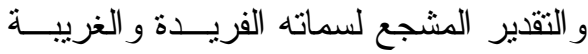
التي يمتاز بها عن زملائه؛ بالإضافة إلـى اختز اعاته و اكتشافاته التي تلقى اســتهجان، ونبذ، ومضايقات ممن حوله؛ فلابـــــــن التعزيز الخارجي سواء كان من المعلمين أو وهي الو الدين حتى يستطيع الموهـــوب إخـــراج إمكاناته، وقدر اته دون حرج؛ بالإضافة إلى لى تهيئة وسائل البحث العلمي، و البيئة الآمنة، و الامكانات اللازمة لاختر اعاته و اكتثافاته، و لايتحقق ذلك إلا بالتعزيز و الدعم الخارجي حتى يكون قادر على مو اصلة تعلمه و إيراز

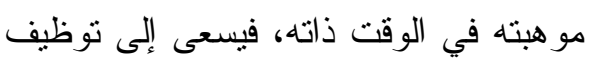

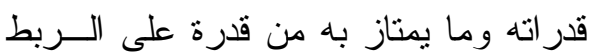




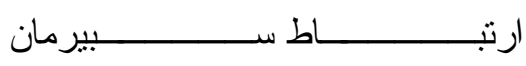

(0.626) وهى قيم دالة إحصائياً عند

$$
\text { مستوي دلالة (0.01). }
$$

وتُفسر الباحثة ذلك بأن الموهوب في الغنــاء

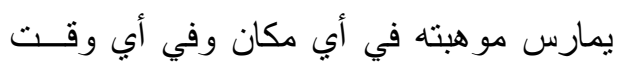

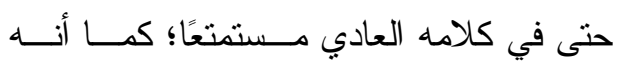
يشعر بأنه يمتلك صوتًا جميلًا فيحول أي كلام إلى أغاني بما فيها المواد الدراسية المقــررة عليه، فهو يستمتع ويمارس موهبته في الغناء، وفي الوقت نفسه يذاكر دروســـه ويجتاز هــــا بسهوله؛ لأنه مستمتع بها، ويحـب لف الاعتمــاد

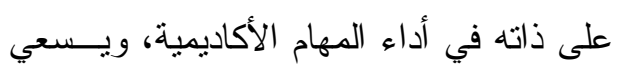
إلى تحقيق الأهداف التي يضعها إرضاءً لذاته لا من أجل إرضاء المعلمين أو الو الدين. وصف نتائج اختبار الفرض الثاني وتفسيرها:

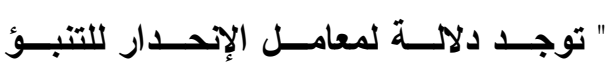
بالتحصيل الأكاديمى لدى الطلاب الموهوبين

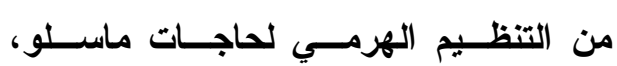
ودو افعهم الداخلية والخارجية

و لاختبار هذا الفرض، قامت الباحثــة

بحساب تحليل الانحــدار المتعـدد المتــدرج

Stepwise Multiple Regression Analysis

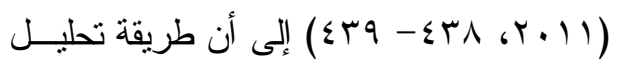

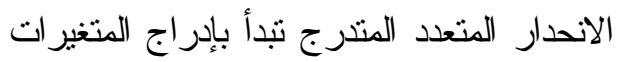

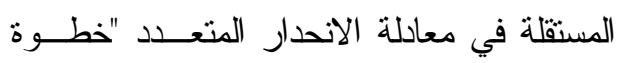

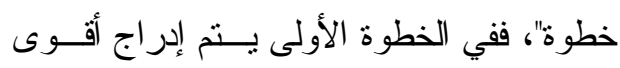

ومنتبهًُا بــل تميــزه بالثبــات و الاســتقر ار

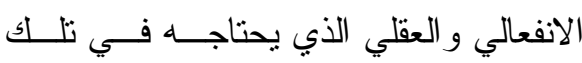

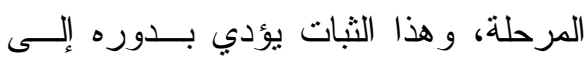
زيادة قدرته على الاستذكار حتى وإن كانت

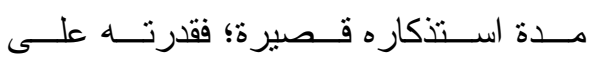

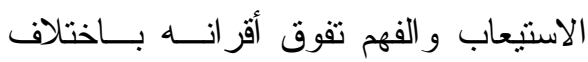
المدى الزمني في الاستذكار ؛ مما يؤدي ذلك بهاب إلى ارتفاع تحصيلهم.

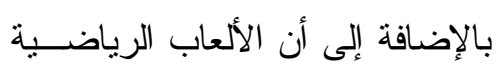
تخلق لدى صاحبها الثقة بالذات و المثــابرة

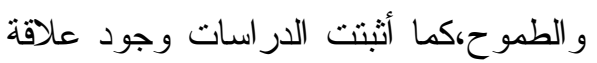

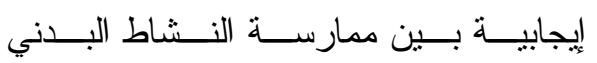

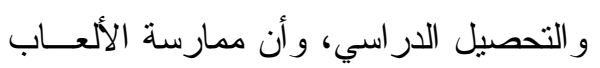

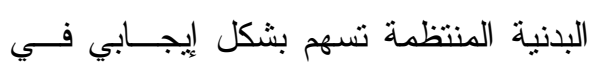
تطوير القدرات العقلية والتحصيل الدراسي لئي لئيل

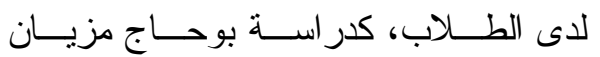
.$(r \cdot 1 \Lambda)$

- توجد علاقة طردية بــين التحــصيل

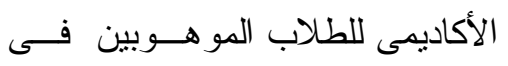
الغناء ودو افعهم الداخلية؛ حيث بلغت

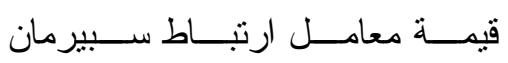

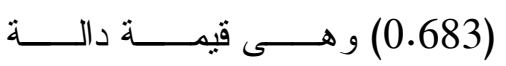

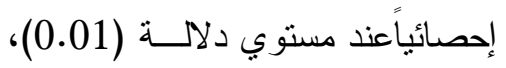

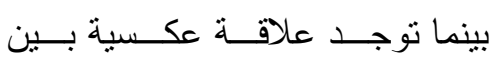

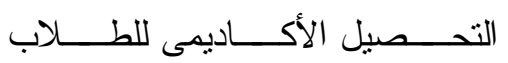

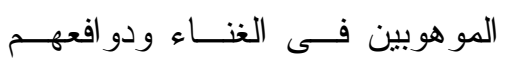
الخارجية؛ حيث بلغت قيمة معامـلـل 
المتغيرات المستقلة تأثيرًا في المتغير التابع في إحصائيًا في المتغير التـابع، أمســا المتغيــرات

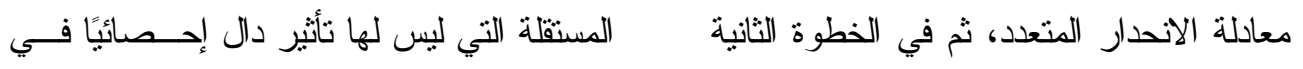

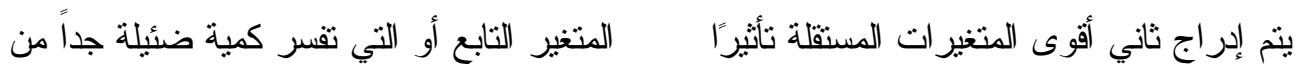

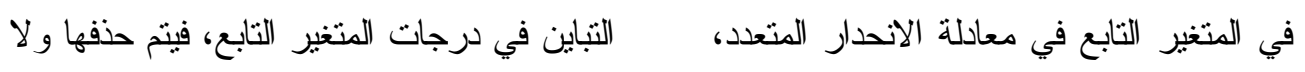

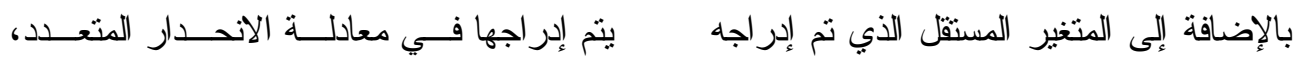

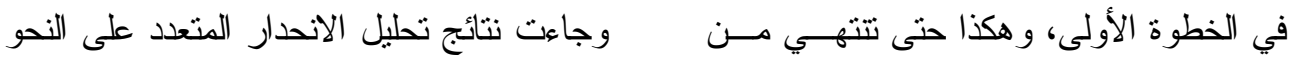
جميع المتغير ات المستقلة التي لها تـأثنير دال الآتى: جدول(ץ) نتائج تحليل الاحدار لمتفيرات التنبؤ (حاجات التنظيم الهرمي لماسلو، و الدوافع

\begin{tabular}{|c|c|c|c|c|c|c|c|c|c|}
\hline Sig. & F & الاندابت & $\mathbf{R}^{2}$ & Sig. & $\mathbf{T}$ & $\begin{array}{c}\text { بيتّ } \\
\text { Beta }\end{array}$ & $\begin{array}{l}\text { المعار } \\
\text { (S.R) } \\
\text { (S.R }\end{array}$ & $\begin{array}{l}\text { الاحدار } \\
\text { (B) } \\
\text { (B) }\end{array}$ & المتغير المنباً \\
\hline 0.01 & 44.5 & 98.7 & 0.306 & 0.01 & -6.668 & -0.553 & 0.082 & -0.550 & للدوافع الخارجية \\
\hline
\end{tabular}

الارتباط المتعدد يساوى (T • ז, ·)، مما

يدل على أن الدوافع الخارجية تفَسِّرّ

يتضح مــن جـدول (Y) أن نتــائج

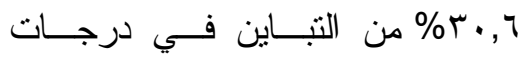

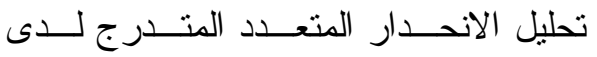

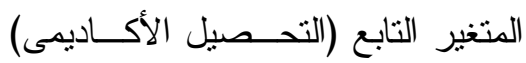

الطلاب الموهــوبين أســفرت عــن إدراج

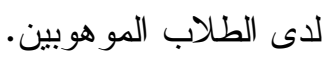

ومما سبق يمكـن صـــاغة معادلـــة الاوافع الخارجية فقط في معادلة الانحـــدار المتعدد باعتبارها أقوى المتغيرات المستقلة

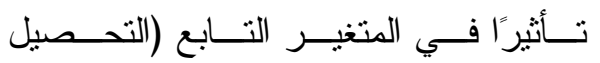

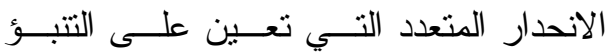
الأكاديمى)، كما يتضح الآتى:

بالتحصيل الأكاديمى من الــدو افع الخارجيـــة

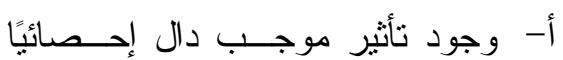
لدى الطلاب الموهوبين في الصورة الآتية:

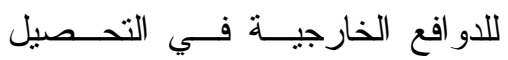

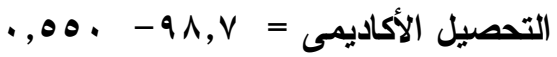

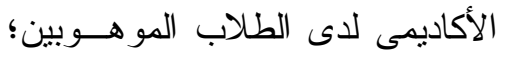

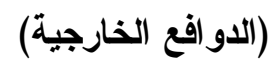

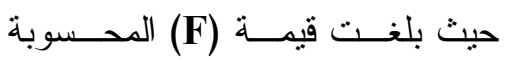

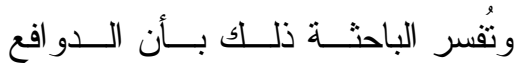

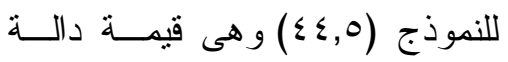

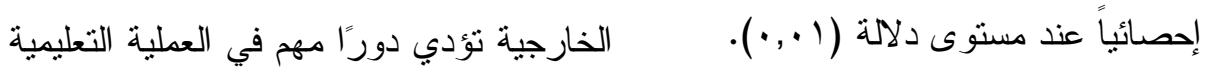

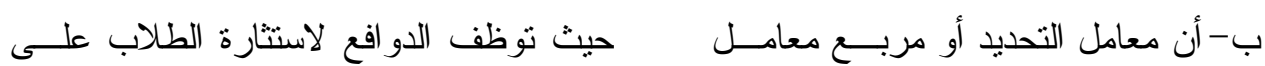


و التحفيز، و الثناء، و المدح، و المكافآت المادية

التعلم، وحفز هم إلى الاكتشاف و الرغبة فــي

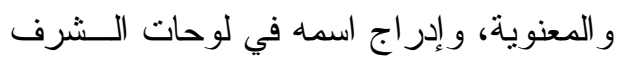

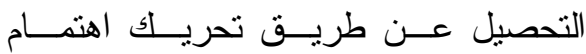

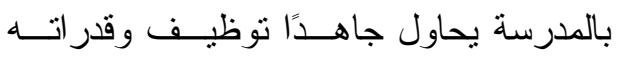

الطلاب، و إثارة دهشتهم، ونتويع الأنـشطة

ومهار اته وسماته التي يمتاز بها عن الآخرين

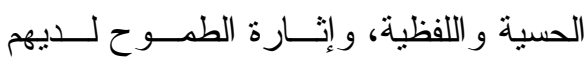

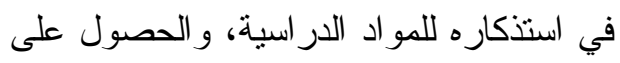

وتــشجيعهم علــى الاســـتـكار و التفـــوق

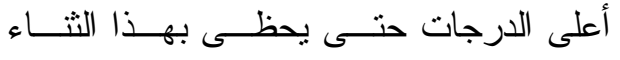

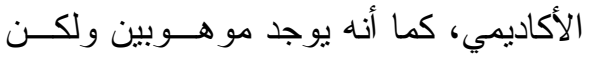

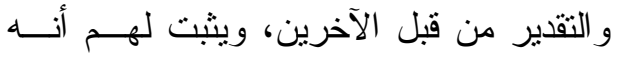

مو هبتهم ليست فعلية؛ حيــث أن الاهتمـــام

يمنلك سمات وقدر اته كافيه لتتمية مو هبته بل ونل

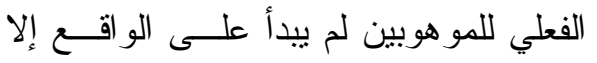

وتفوقه الأكاديمي.

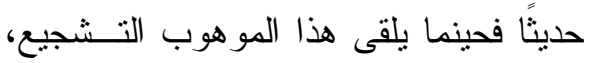

ملخص لنتائج الفرض

\begin{tabular}{|c|c|}
\hline & \\
\hline 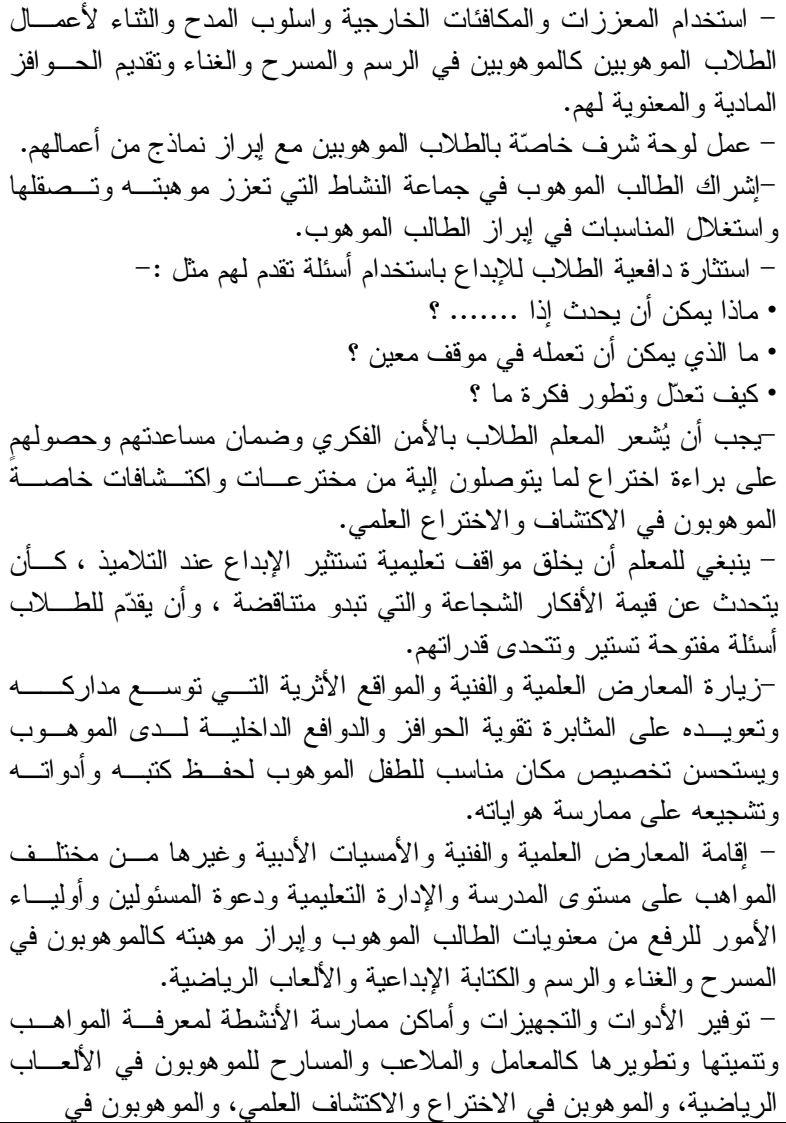 & 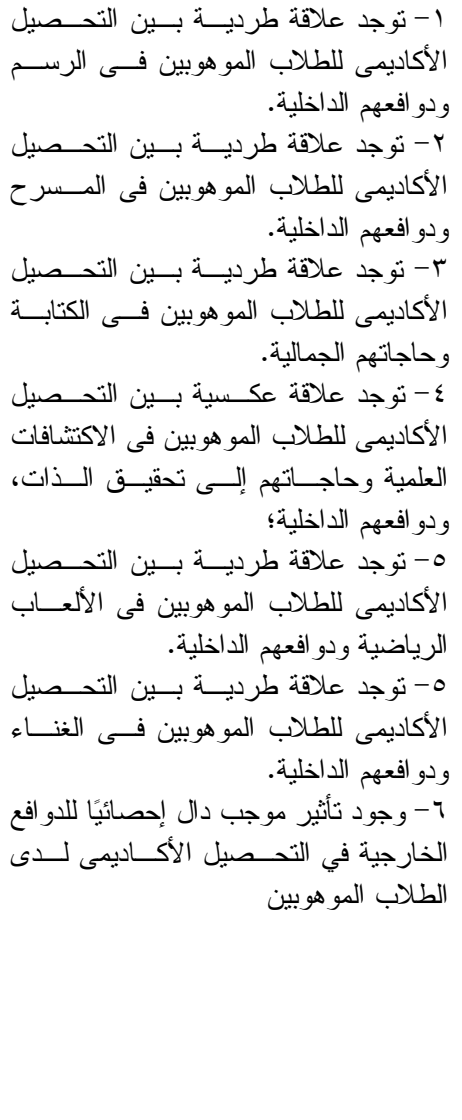 \\
\hline
\end{tabular}




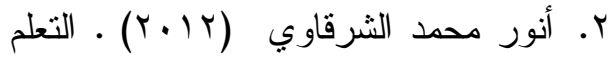

نظريات وتطبيقات ـ القـــاهرة ، مكتبـــة

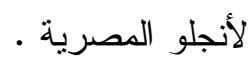

r. أنور محمد الثرقاوي (ب/91). الــتعلم نظريات وتطبيقــات. القــاهرة، مكتبـــة الأنجلو المصرية.

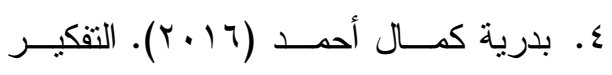
الابتكاري لــدي عينــة مــن الطــلاب

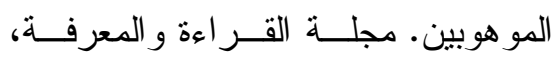

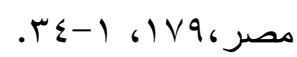
ه. بوحاج مزيان (1) (†). دو افــع ميــول

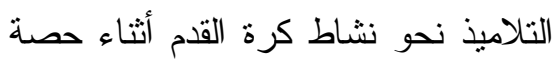

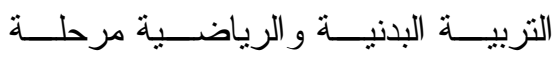
الثانوية.مجلة الابداع الرياضي ، البويرة، لرئه $9 \cdot-V V \cdot(1)^{9}$ T. تيسير مفلح كو افحة (ع . . ب). علم النفس

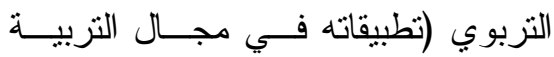
الخاصة). عمان، دار المسيرة. V. جيلاني بوحمامسـة (9 . . . . . الدافعيــة

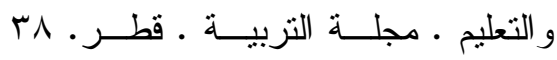
. IVA -10N. (1V.)

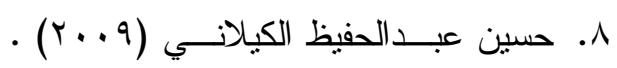
الموهبة و التفكير الإبداعي في التعلــيم . الأردن ، دار دجلة للنشر عمان .

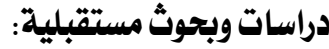

تقتــرح الباحثــة إجــر اء بحــوث فــي الموضو عات التالية:

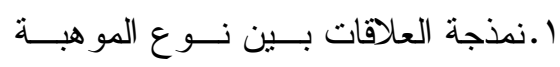

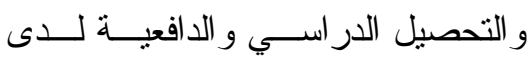

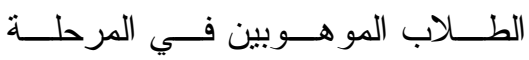
الثانوية. r.مدى تمايز الدافعية بـين الموهـــين

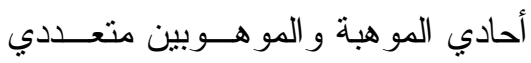
الموهبة و أثزه على التحصيل الدراسي ولي هوبين في المرحلة الثانوية.

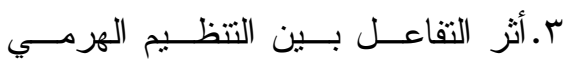
للحاجات عند ماسلو وأساليب التفكيـر على التحصيل الدراسي لاعى الطــلاب

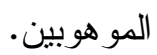

ـ. التنبؤ بالتحصيل الدر اسي مـن خــلال

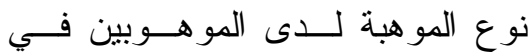
المرحلة الثانوية . لمونه

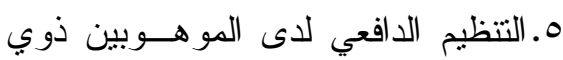

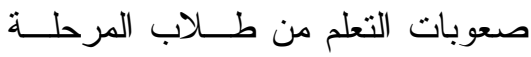
الإعدادية.

\section{مراجع}

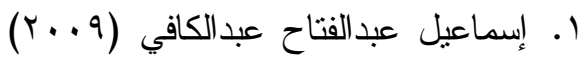
تنمية الموهبة لدى الأطفال ـ القاهرة

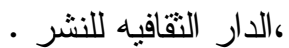




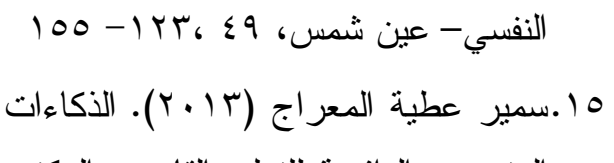

المتعددة و الدافعية للتعلم. القاهرة، المكتب التب

$$
\text { العربي للمعارف. }
$$

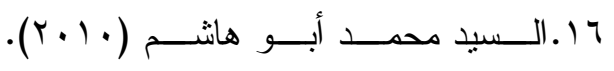

المعتقدات المعرفية و التوجهات الدافعيــة

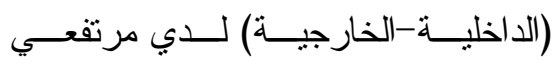

ومنخفضي التحصيل الدر اسي من طلاب

الجامعة. ورقة مقدمة إلي المؤتمر العلمي

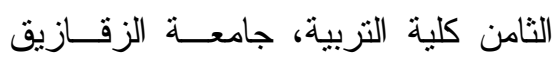

بعنوان (استثمار الموهبة ودور مؤسسات

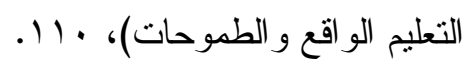

IV

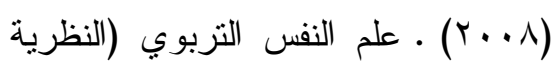

و النطبيق ). (طץ). الأردن، دار المسيره

$$
\text { للطباعة و النشر . }
$$

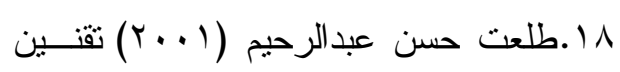
مقياس " جيمس" لوجهة التحكم الــداخلي

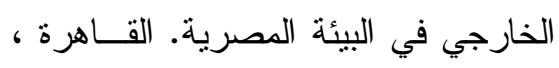

$$
\text { دار الفكر العربي. }
$$

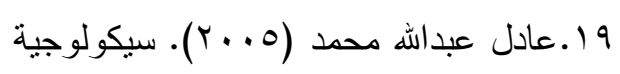

$$
\text { المو هبة. القاهرة، دار الرشاد. }
$$

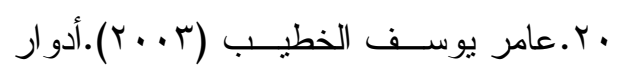

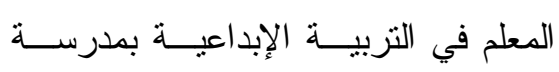

الموهوبين.المؤتمر العلمي العربي الثالث

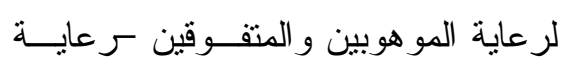

9. حمدان محمد علي إسماعيل (· ( ·).

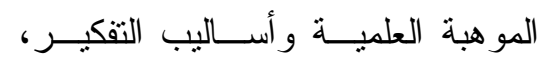

$$
\text { القاهرة، دار الفكر العربي. }
$$

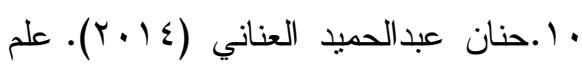

النفس التزبــوي. (طه)، عمـــان، دار

صفاء للنشر .

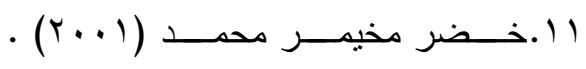

الفاعلية الذاتية لاى طلاب السنة النهائية

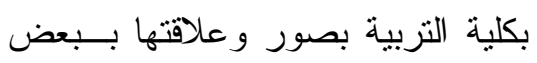

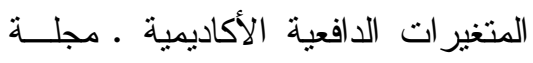

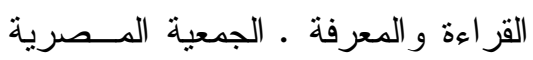

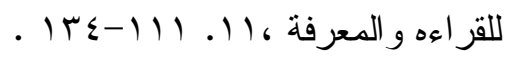

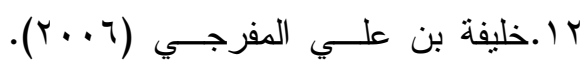

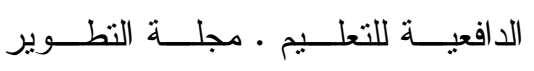

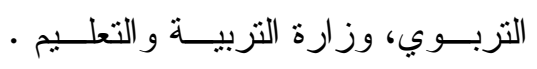

$$
\text { . IV-IT. (r) }
$$

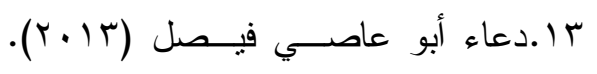

إدارة الوقت لدي الموهوبين أكاديميــاً

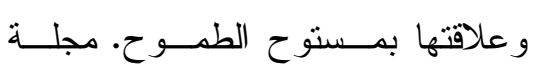

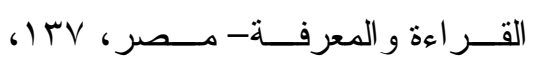

$$
. r \cdot \varepsilon-I V T
$$

ع ا.سميحان بن ناصر الرشيدي (YlV)

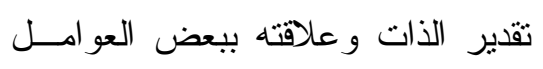

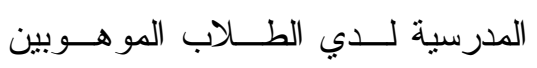

بمحافظة الإحسـاء. مجلــة الإرشــاد 
باستخدام برنامج SPSS. القــاهرة ، دار

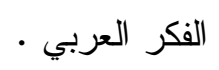

rV

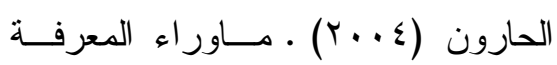

و استر انتيجيات التذكر و الدافعيــة للــتـعلم

كنغير ات تتبؤيه للتحصيل الأكاديمي لدى

طلاب التعليم الثانوي العام ـ مجله كليــــة

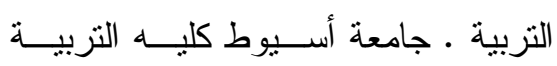

$$
.0 \leqslant-1(r) Y \text {. }
$$

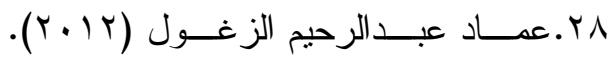

مبادئ علم النفس التربوي. (طب)، العين

$$
\text { بدولة الإمار ات، دار الكتاب الجامعي. }
$$

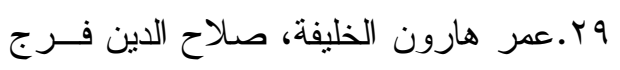

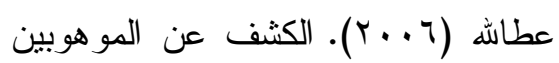

متدني التحصيل الدراسي. ورقة مقدمسـة

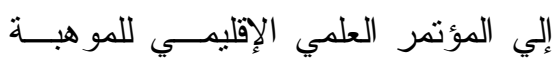

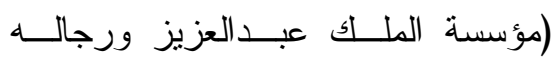

للمو هبة بجدة )، مجلة الدر اسات العلميــة

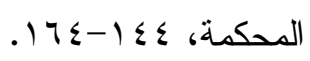

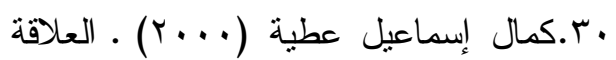
بين أبعاد التعليم المنظم ذاتياً لدى طالبات

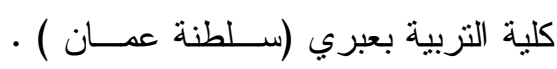
مجلة البحوث النفسية و التزبوية ـ جامعة

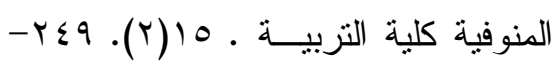

المو هوبين و المبدعين أولوية عربية في عصر العولمة- مؤتمر المجلس العربي

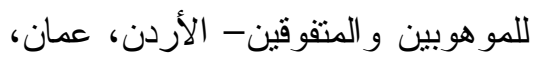
Trוا. .عبد الستار إبر اهيم، رضوي إبــر اهيم (Y..T) در سته. (طץ). القاهرة، مكتبة الأنجلو

$$
\text { المصرية. }
$$

r Y.عبداله أحمد هياس، أحمــد الــشباطات

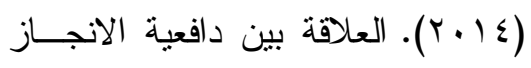

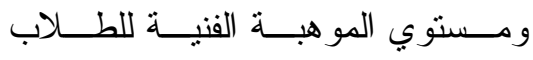
الموهوبين بمنطقـــة الباحسـة. رســـالة ماجستير غير منشورة، جامعة الباحة.

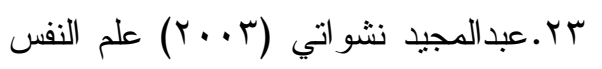
التربوي ـ الأردن ، دار الفرقان للنشر

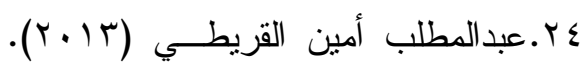
الموهوبون و المتفوقــون (خصائـــهـم و اكتشافهم ورعايتهم ). القاهرة، عـالم

$$
\text { الكتب. }
$$

OY.عـــنان العتـــوم، شـــفيق علاونــــة،

عبدالناصر الجراح، معاوية أبــــوغز ال

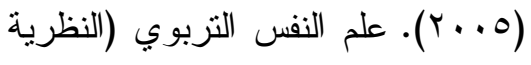

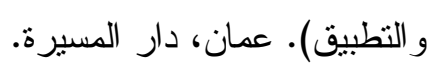

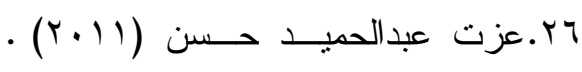
الإحصاء النفسي و التزبوي ـ تطبيقــات 


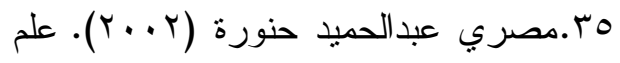

نفس الأدب وتربيــة الموهبـــة الأدبيــة.

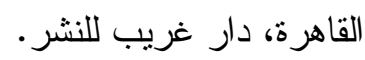

4r.ممدوح عبدالمنعم الكناني (9AV) (1 ).مدى

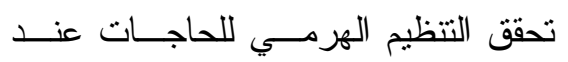

ماسلو .القاهرة، مكتبة ومطبعة مصر .

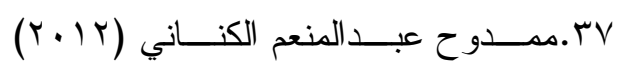

الإحصـاء النفسي و التزبـــوي، القـــاهرة ،

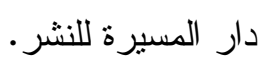

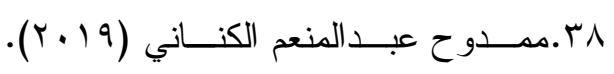

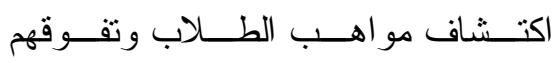

الأكاديمي. القاهرة مكتبة الفلاح

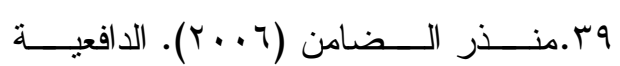

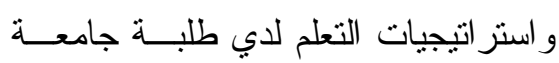

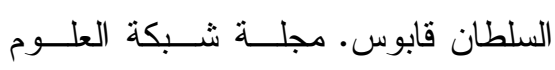

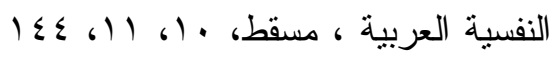

.10. -

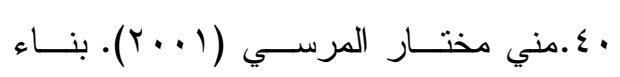

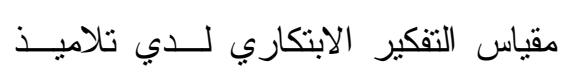

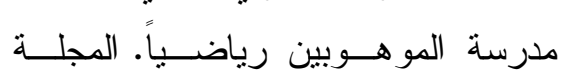

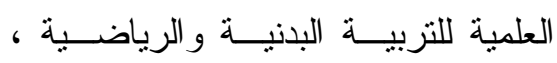

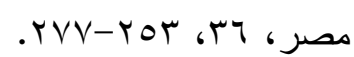

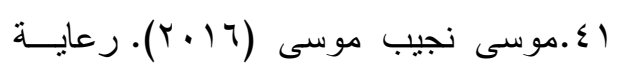

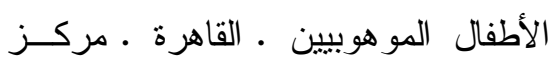

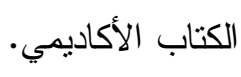

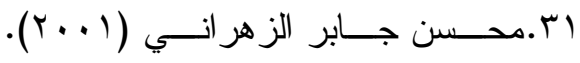

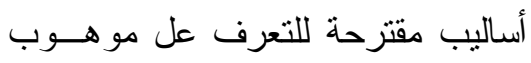

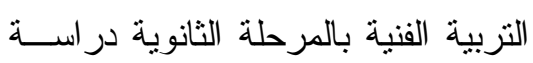

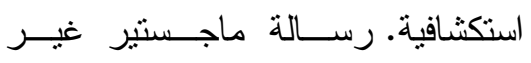

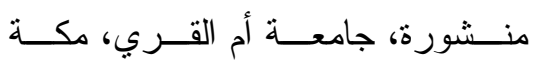

$$
\text { المكرمة. }
$$

r. بحمد رفقي عيسى (911 (1). الدافعيــة در اسة نقدية مع نموزج مقترح. الكويت

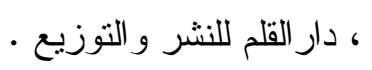

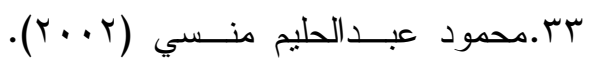

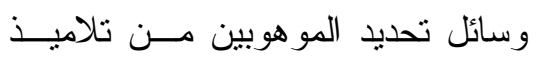
المدارس بالتعليم العام. المؤتمر العلمي هوني نداني

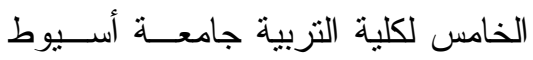
( تربية الموهوبين و المتفوقين المــدخل إلي عصر التميز والابــداع )، (1)، (1)، أسيوط، كلية التزبية ، جامعة أســيوط،

$$
\text { . } \varepsilon r \cdot-\varepsilon r r
$$

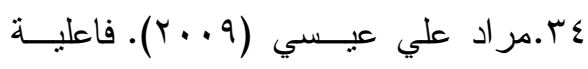

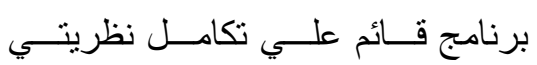

الأكاءات المتعددة و أساليب التعلم فــي في

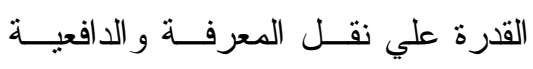

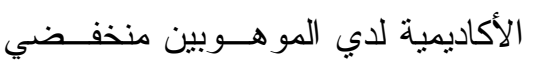

التحصيل من تلاميذ المرحلة الإبتدائية.

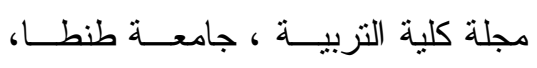

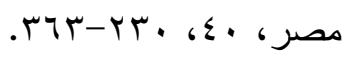


dissertation، University of Education in partial fulfillment ).

47. Davie، J. L. (2012). Giftedness and underachievement. A comparison of student groups (Doctoral dissertation، University of Minnesota).

48. Deci، E.، \& Ryan، R. (2000). The "what" and "why" of goal pursuits: Human needs and the self-determination of behavior. Psychological Inquiry، 11، 227268

49. Gagné، F.(2004).Transforming gifts into talents. The DMGT as a developmental theory. High ability studies، 15(2)، 119-147.

50. Kay،S.I.(2008).Nurturing visual arts talent. Gifted Child Today، 31(4)، 19-23

\section{Lepper،M.،Corpus،J.‘\&}

Iyengar، S.(2005). Intrinsic and extrinsicmotivational orientations in the classroom. Age differences and academic correlates. Journalof educational psychology، 97(2)، 184.

52. Maddox، M. (2014). Exploring teachers'experiences of working with gifted students who underachieve (Doctoral

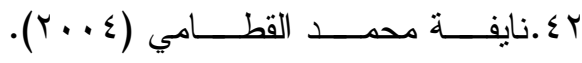

$$
\begin{aligned}
& \text { لإستر اتيجيات المعرفية للتعلم المــنظم } \\
& \text { ذاتياً للطلبة الجامعيين و علاقتها بمتغير } \\
& \text { التحصيل الدراسي و المرونة المعرفيــة } \\
& \text { و الدافعية المعرفية ـ مـستقبل الثربيــة }
\end{aligned}
$$

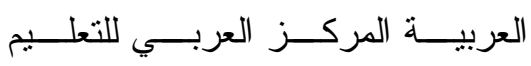

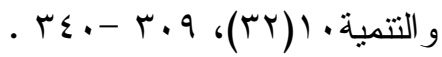

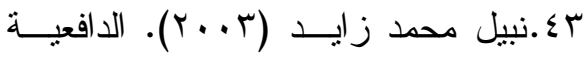

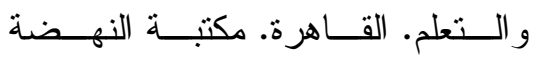

$$
\begin{aligned}
& \text { المصرية. }
\end{aligned}
$$

44. Abu-Hamour‘B.`\&Al-Hmouz، H. (2013). A Study of Gifted High،Moderate،andLow Achievers in Their Personal Characteristics and Attitudes toward School and Teachers. International journal of special education، 28(3)، 515.

\section{Carson`S.،Peterson`J،\&}

Higgins،D. (2005). Reliability، validity، and factor structure of the creative achievement questionnaire. Creativity Research Journal، 17(1)، 3750.

46. Clevenger، E. (2013). Relation of Theory of Intelligence to Academic Motivation and Academic Outcomes (Doctoral 
environmental variables. High

ability studies، 13(1)، 59-74.

57. Renzulli، J.، \& Renzulli، S.(2010). The schoolwide enric hment model. A focus on student strengths and interests. Gifted Education International، 26(2-3)، 140-156.

58. Rush،E.(2012).Motivation of

Academically Gifted Students. OnlineSubmission 10 2. https://files.eric.ed.gov/fulltext/ ED532474.pdf

59. Sealy، S. (2012). Impact of

Freshman

Experiences

Academic

Motivation

Dissertations.

andProjects68..https://digitalco

mmons.gardner-

ebb.edu/education etd/6.

60. Sternberg، R.، \& Zhang، L.(1995). What do we mean by giftedness? A pentagonal implicit theory. Gifted Child

Quarterly، 39(2)، 88-94. dissertation،

Walden

University).

53. Marland Jr، S.. (1971).

Education of the Gifted and Talented-Volume 1. Report to the Congress of the United States by the US Commissioner of Education.

54. Matthews، M. S.، Ritchotte، J. A.، \& Jolly، J. L. (2014). What's wrong with giftedness? Parents' perceptions of the gifted label. International Studies in Sociology of Education، 24(4)، 372-393.

55. Maslow، A. (1954).

Motivation and personality. New York، Harper \& Brothers،

56. Neber، H.6 \& SchommerAikins، M. (2002). Selfregulated science learning with highly gifted students: The role of cognitive, motivational، epistemological‘and 